
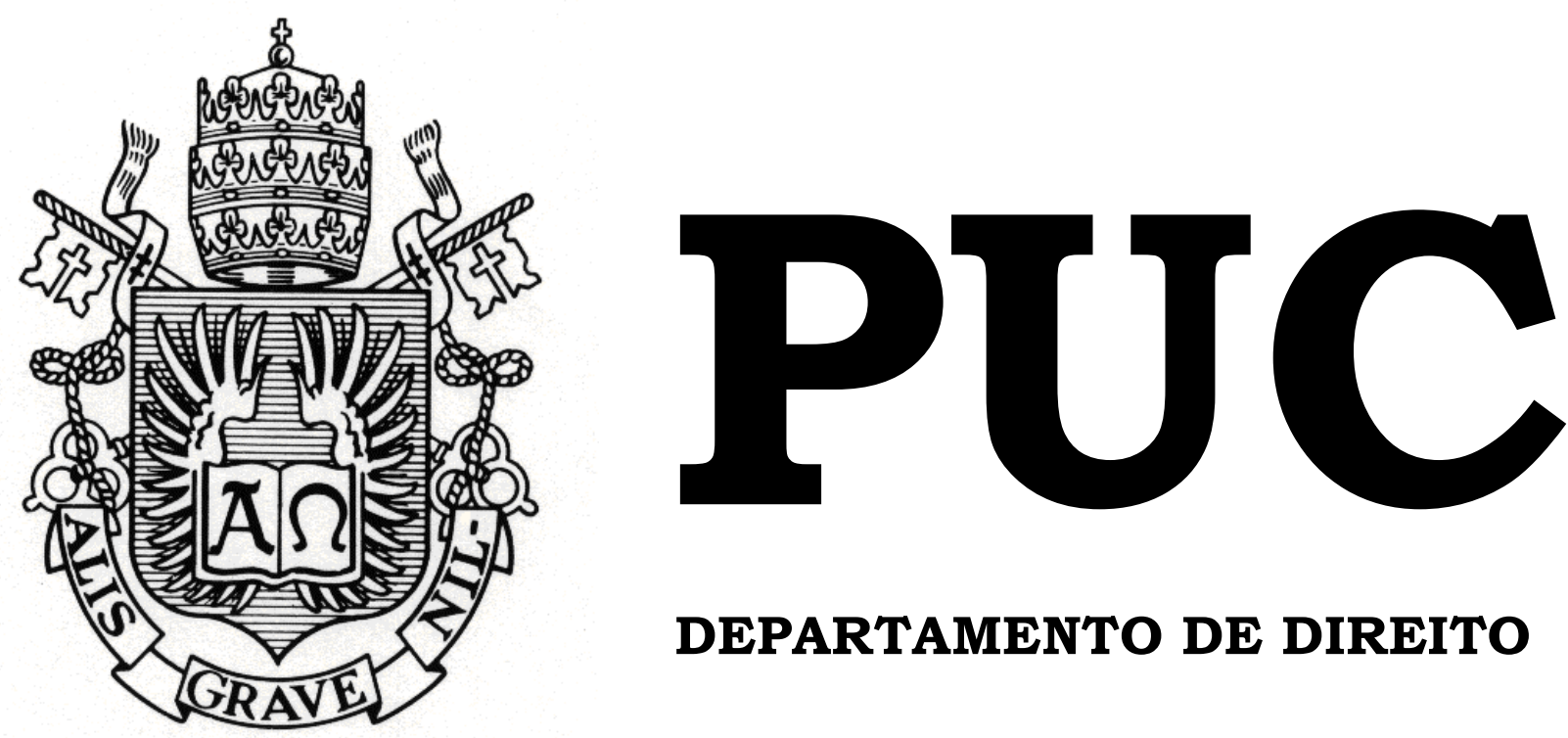

DEPARTAMENTO DE DIREITO

\title{
O IMPACTO DA CAUSALIDADE NA QUANTIFICAÇÃO DA INDENIZAÇÃO: CULPA CONCORRENTE, CONCAUSA E CAUSA VIRTUAL
}

Por

LUIZ FELIPE GOES DE ANDRADE MENDES DE ALMEIDA

ORIENTADOR: JOSÉ ROBERTO DE CASTRO NEVES 2018.2

PONTIFÍCIA UNIVERSIDADE CATÓLICA DO RIO DE JANEIRO

RUA MARQUÊS DE SÃO VICENTE, 225 - CEP 22451-900

$$
\text { RIO DE JANEIRO - BRASIL }
$$




\title{
O IMPACTO DA CAUSALIDADE NA QUANTIFICAÇÃO DA INDENIZAÇÃO: CULPA CONCORRENTE, CONCAUSA E CAUSA VIRTUAL
}

por

LUIZ FELIPE GOES DE ANDRADE MENDES DE ALMEIDA

\author{
Monografia apresentada ao \\ Departamento de Direito da \\ Pontificia Universidade Católica do \\ Rio de Janeiro (PUC-Rio) para a \\ obtenção do Título de Bacharel em \\ Direito.
}

Orientador: José Roberto de Castro Neves 


\section{AGRADECIMENTOS}

A conclusão deste trabalho simboliza o fim de um ciclo. Justamente por isso, não poderia deixar de agradecer a todos aqueles que contribuíram, ao longo desses anos, para o meu crescimento pessoal e profissional.

Agradeço, inicialmente, aos meus pais, Mônica e Pedro, pelo apoio incondicional em todos os momentos da minha vida. O seu carinho, apoio, força e amor foram combustíveis essenciais para a conclusão de todas as etapas que até agora atravessei. Essa, a mais dura e cansativa de todas, tornou-se mais suave com a segurança e o conforto que vocês sempre me proporcionaram. A vocês, devo a minha vida.

À minha irmã Carol, com quem tenho o privilégio de aprender, diariamente, o verdadeiro significado das palavras generosidade, companheirismo e amor. Sem o seu apoio, nada disso seria possível.

Aos meus avós, em especial ao meu avô materno, José Goes de Andrade, com quem tive o prazer, ainda criança, de colher valiosas lições que carrego para toda a eternidade. O tempo não nos permitiu compartilhar experiências jurídicas, mas a sua família, os seus amigos, os seus livros e histórias são os maiores testemunhos de suas conquistas e qualidades.

À minha família do Ferro, Castro Neves, Daltro e Gomide Advogados, que, além de profissionais extraordinários, são amigos que carregarei à vida toda. Com vocês, o trabalho tornou-se mais prazeroso e os finais de semana mais divertidos. Sem vocês, não seria metade do que penso ser hoje. Agradeço especialmente aos advogados Luciano Gouvêa Vieira, Francisco Gracindo e Pedro Ivo Bobsin, que aceitaram a difícil missão de transformar um garoto em advogado. Vocês, além de profissionais excepcionais, foram 
responsáveis por toda a minha evolução profissional ao longo desses últimos três anos.

Aos amigos do GEADICI, por terem me proporcionado a melhor experiência que a faculdade poderia me oportunizar. Agradeço, acima de tudo, pela paciência e amizade.

Ao meu querido amigo, irmão e colega de trabalho, Enrico, não apenas pelo auxílio na idealização deste tema, mas, principalmente, pela amizade.

Ao Professor, mentor, e orientador, José Roberto de Castro Neves, com quem tenho o privilégio de estagiar há mais de dois anos. Você, em meio à correria do dia-a-dia, orientou muito mais do que este trabalho, foi responsável pela minha evolução profissional e, por isso, serei eternamente grato. 


\section{RESUMO}

ALMEIDA, Luiz Felipe Goes de Andrade Mendes de. O impacto da causalidade na quantificação da indenização: culpa concorrente, concausa e causa virtual. Rio de Janeiro: 2018: 57 p. Monografia de final de curso. Departamento de Direito da Pontifícia Universidade Católica do Rio de Janeiro - PUC-Rio.

O presente trabalho tem como objetivo promover uma análise acerca da influência da causalidade na quantificação da indenização. De início, demonstraremos a importância da causalidade à responsabilidade civil. Em seguida, introduziremos os fundamentos básicos de cada uma das teorias da causalidade, assim também como as dificuldades enfrentadas pela jurisprudência em sua aplicação. Por fim, investigaremos, a partir da concorrência de causas real e virtual, as formas pelas quais a causalidade pode influir na quantificação da indenização. Desse modo, o trabalho será concluído apontando os cenários em que a concorrência de causas pode efetivamente reduzir o quantum indenizatório.

Palavras-Chave: Direito Civil - Responsabilidade Civil Causalidade - Nexo Causal - Concorrência de Causas - Concausa - Culpa Concorrente - Condições Preexistentes - Causa Virtual - Causa Hipotética - Relevância Negativa - Indenização. 


\section{SUMÁRIO}

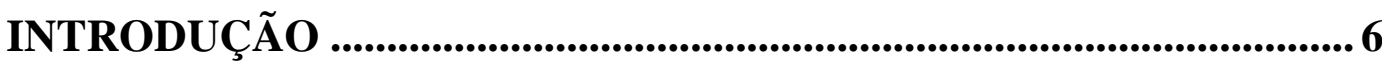

CAPÍtULO 1 - 0 "GIRO CONCEITUAL" DO NEXO DE CAUSALIDADE NA RESPONSABILIDADE CIVIL ............................... 8 CAPÍTULO 2 - NEXO CAUSAL: PRINCIPAIS TEORIAS E SUA APLICAÇÃO PELO PODER JUDICIÁRIO............................................. 12

2.1. Teoria da equivalência das condições ............................................... 13

2.2. Teoria da causalidade adequada ...................................................... 15

2.3. Teoria da causalidade necessária..................................................... 19

2.4. Jurisprudência brasileira: uma aplicação confusa das teorias da

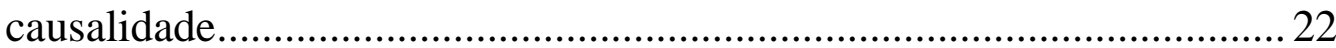

CAPÍtULO 3 - AS CONCAUSAS E SEUS EFEITOS NA QUANTIFICAÇÃO DA INDENIZAÇÃO................................................ 28

3.1. Concorrência real de causas .............................................................. 30

3.1.1. Concurso entre fatos do lesado e do responsável ........................... 30

3.1.2. Concurso entre fato do lesante e as condições preexistentes da

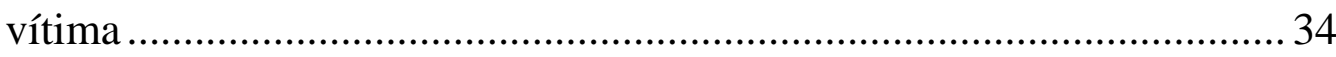

3.1.3. Concurso entre fatos de várias pessoas ........................................... 37

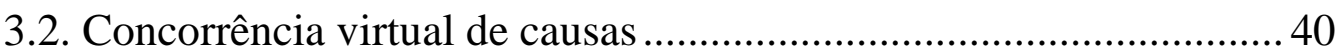

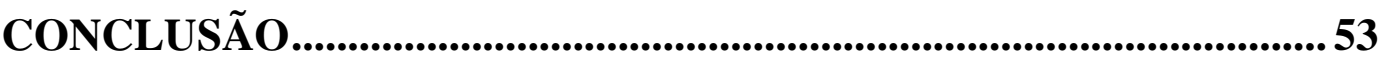

REFERÊNCIAS BIBLIOGRÁFICAS ..................................................55 


\section{INTRODUÇÃO}

O presente trabalho pretende demonstrar a importância da causalidade para a quantificação da indenização na responsabilidade civil. Com efeito, durante muito tempo, a culpa figurou como principal responsável pela variação do quantum indenizatório. Neste trabalho, analisa-se a responsabilidade civil sob o viés da causalidade. Para tanto, esta monografia examinará a repercussão da concorrência real e virtual de causas na fixação do quantum indenizatório.

No Capítulo 1, introduziremos a importância da causalidade a partir de uma análise histórica e social. Nessa parte, será demonstrado como o surgimento da responsabilidade civil objetiva elevou a relevância da causalidade na configuração do dever de reparar, transformando o nexo causal em último filtro à responsabilização civil.

Em seguida, o Capítulo 2 exporá as diversas teorias da causalidade, desenvolvidas ao longo dos séculos para identificar quais fatores podem ser compreendidos como determinantes à produção do dano. Nessa parte, revelaremos as dificuldades enfrentadas pelos Tribunais pátrios quanto à aplicação das teorias da causalidade, assim também como as confusões promovidas pela jurisprudência.

No Capítulo 3, procurar-se-á evidenciar a influência da causalidade na quantificação da indenização. Para tanto, analisaremos os efeitos da concorrência de causas sobre o valor das indenizações. A análise levará em consideração os seguintes cenários: (i) concurso entre fatos do lesado e do responsável - equivocadamente chamado de "culpa concorrente" -; (ii) concurso entre fato do lesante e condições preexistentes da vítima; (iii) concurso entre fatos de várias pessoas; e (iv) concurso virtual de causas.

Com tudo isso, pretende-se atribuir à causalidade a sua devida importância, demonstrando as formas pelas quais a concorrência de causas 
pode influir no quantum indenizatório. Nessa tarefa árdua, espera-se ponderar o direito da vítima à indenização com o direito do lesante de responder apenas pelo dano que efetivamente decorreu de sua conduta. 


\section{CAPÍTULO 1 - 0 “GIRO CONCEITUAL" DO NEXO DE CAUSALIDADE NA RESPONSABILIDADE CIVIL}

A simplicidade do sistema brasileiro de responsabilidade civil fez com que CAVALIERI o comparasse a um "samba de uma nota só". Tal comparação não foi nada injusta, afinal, à época, a culpa era a verdadeira estrela do instituto, de modo que "nada acontecia sem a sua participação",2.

No início do século XX, pode-se dizer que o sistema brasileiro de responsabilidade civil era extremamente simples. Sob a égide do Código Civil de 1916, compreendia-se apenas a responsabilidade subjetiva, prevista no art. 159 do referido diploma civil, de sorte que o próprio estudo do instituto da responsabilidade civil não demandava maiores esforços.

Ocorre que, ao longo do século XX, a humanidade presenciou uma explosão revolucionária sem precedentes em todos os campos do conhecimento. A invenção do computador por Alan Turing, a teoria da relatividade geral elaborada por Albert Einstein e a ida do homem ao espaço foram alguns dos diversos avanços tecnológicos da humanidade naquele século.

Por outro lado, foi também uma época sombria, marcada por guerras devastadoras, que afetaram profundamente os relacionamentos e os comportamentos da sociedade. O ódio demonstrado nas guerras foi seguido da busca incessante pela justiça social, através da qual se pretendia construir uma sociedade solidária.

O aumento expressivo da capacidade produtiva humana e, consequentemente, a elevação do número de acidentes corporais, assim também como a maior intervenção do Estado na economia e nos direitos

\footnotetext{
${ }^{1}$ CAVAliERI FILHO, Sérgio. Programa de Responsabilidade Civil. 11 ${ }^{\text {a }}$ ed., São Paulo: Atlas, 2014. p. 2.

${ }^{2}$ Ibid., p. 2.
} 
sociais, fez com que o instituto da responsabilidade civil sofresse uma enorme revolução, por meio da qual promoveu-se a ampliação e o fortalecimento da responsabilidade civil objetiva.

Com a evolução do instituto da responsabilidade civil - e sua maior flexibilização, a partir da dispensa, em determinados casos, do requisito da culpa -, o nexo causal tornou-se peça fundamental na configuração do dever de reparar. Nesse sentido, adverte SCHREIBER:

(...) o advento da responsabilidade objetiva veio transformar radicalmente a atuação das cortes em geral, exigindo redobrada atenção na decisão acerca do nexo causal, cuja interrupção consiste, em tais hipóteses, no único caminho concedido ao réu para o afastamento da condenação. Assim, não apenas o convencimento acerca da causalidade perdeu seu antecedente moral justificador da responsabilidade - a prova da culpa -, mas também toda a discussão, nas ações de responsabilidade objetiva, passou a gravitar em torno da noção jurídica de nexo causal ${ }^{3}$.

Se, antes, o instituto da culpa era o centro das as atenções, hoje, o nexo causal tomou o seu lugar, tornando-se objeto de diversos debates, dentre os quais inclui-se a interferência da causalidade na quantificação da indenização.

Com efeito, não há como se falar em responsabilidade civil, sem, antes, proceder à verificação da existência (ou não) de um nexo de causalidade entre a conduta tida por lesiva e o dano gerado ao lesado ${ }^{4}$. Justamente por isso, nas palavras de ALVIM, “o dano só pode gerar responsabilidade quando seja possível estabelecer um nexo causal entre êle e o seu autor" 5 .

Assim, identifica-se a primeira função do nexo causal na responsabilidade civil, qual seja, identificar o responsável pelo evento danoso.

\footnotetext{
${ }^{3}$ SCHREIBER, Anderson. Novos Paradigmas da Responsabilidade Civil: da erosão dos filtros da reparação à diluição dos danos. São Paulo: Atlas, 2007. p. 51-52.

${ }^{4}$ PEREIRA, Caio Mário da Silva. Responsabilidade civil. $5^{\mathrm{a}}$ ed. Rio de Janeiro: Forense, 1994. p. 75.

${ }^{5}$ ALVIM, Agostinho. Da inexecução das obrigações e suas consequências. São Paulo: Saraiva, 1972. p. 340 .
} 
Mas não é só. O nexo causal comporta uma dupla função ${ }^{6}$, de modo que, além de individualizar o autor (ou autores) do ato lesivo, possui ele também a atribuição de verificar a extensão do dano. Sobre o assunto, discorre PONTES DE MIRANDA:

Para se pensar em extensão do dano tem-se de partir do nexo causal. A indenizabilidade do dano é na medida em que ele se acha em relação à causa, ou às concausas, ou à causa de aumento. Tem-se de considerar o prejuízo que o ofendido sofreu, ou sofreu e ainda vai sofrer, e o que pode haver lucrado, bem como a sua participação nas causas do dano ou no aumento desse ${ }^{7}$.

Desse modo, a importância do nexo causal na responsabilidade civil reside no fato de que a sua verificação pode influir diretamente no afastamento do dever de reparar, ou, no limite, na redução do valor a ser indenizado ao lesado - este último, foco do presente trabalho. Tem-se, portanto, respectivamente, as causas excludentes de nexo causal (fato exclusivo da vítima, fato de terceiro, caso fortuito e força maior) - as quais resultam na exclusão da responsabilidade civil -, e a concorrência de causas, que implicam na redução do quantum indenizatório.

Diferentemente da demonstração de sua importância, a conceituação do nexo de causalidade é tarefa extremamente árdua e difícil ${ }^{8}$. Isso porque, segundo EWALD, "a realidade não corresponde ao esquema demasiado simples de uma conduta-causa que produz um dano-efeito", e continua, "as

\footnotetext{
${ }^{6}$ FROTA, Pablo Malheiros da Cunha. A imputação sem nexo causal e a responsabilidade por danos. Curitiba, 2013. Tese (Doutorado). Universidade Federal do Paraná. pp. 100-103.

${ }^{7}$ PONTES DE MIRANDA, Francisco Cavalcanti. Tratado de direito privado. t. XXII. $3^{\mathrm{a}}$ ed. Rio de Janeiro: Editora Borsoi, 1971. p. 206.

${ }^{8} \mathrm{Um}$ dos pontos mais difíceis da responsabilidade civil é este de saber que danos acontecidos podem ser considerados causados por um determinado fato. Nem sempre é fácil saber se a contribuição de um fato para um dano é suficiente para que se deva considerá-lo gerador deste. Por outro lado, pode também acontecer que um só dano deva ser atribuído a diversas causas. Pode ainda haver vários danos, e de diversa natureza (patrimoniais e extrapatrimoniais, presentes e futuros etc.), todos ligados a um só fato, ou a diversos, sem se saber quais são os danos que foram determinados por cada fato. Às vezes, além do dano imediatamente causado por um certo fato, tido como gerador da responsabilidade, surgem outros danos (danos indiretos), que possivelmente não teriam acontecido se não fosse aquele fato, mas não se sabe se devem ser considerados. NORONHA, Fernando. O nexo de causalidade na responsabilidade civil. In: Revista dos Tribunais. v. 816, p. 733, 2003.
} 
coisas, nem pelo lado da causa, nem pelo lado do efeito, nunca são tão bem delimitadas $"$.

Tendemos a concordar com o autor francês. Com efeito, não raras vezes, a realidade nos fornece casos cujas particularidades desafiam todas as teorias já elaboradas pelo homem, forçando-nos a relativizar conceitos e interligar teorias, a fim de fornecer à sociedade uma justificativa lógica para cada caso. Na tentativa de conceituar o termo nexo causal, SCHREIBER adverte seus leitores quanto à ilusória simplicidade da tarefa:

O nexo causal, ou relação de causalidade, vem usualmente definido como o vínculo que se estabelece entre dois eventos, de modo que um represente consequência do outro. A aparente simplicidade da definição contrasta com as inúmeras dificuldades práticas que surgem na sua aferição. A respeito da matéria, já se advertiu, entre nós, que o nexo de causalidade consiste no "mais delicado dos elementos da responsabilidade civil e o mais difícil de ser determinado" 10 .

Feitos esses esclarecimentos, exporemos duas simples, porém abalizadas, definições acerca do nexo de causalidade. Para GONÇALVES, o nexo causal seria "uma relação necessária entre o fato incriminado e o prejuízo"11. Já para NORONHA, a "causa de um dano é o fato que contribuiu para provocá-lo, ou para agravar os seus efeitos" ${ }^{12}$.

A semelhança entre tais definições em nada reflete uma suposta pacificação quanto à definição do conceito de nexo causal. Como se demonstrará no capítulo seguinte, duas das principais teorias desenvolvidas pela doutrina na tentativa de solucionar o problema, continuam sendo, de forma discricionária, aplicadas, concomitantemente, pelo Poder Judiciário.

\footnotetext{
${ }^{9}$ EWALD, François. Foucault, a Norma e o Direito. $2^{\text {a }}$ ed. Lisboa: Vega, 2000. p. 169.

${ }^{10}$ SCHREIBER, 2007, p. 51-52.

${ }^{11}$ GONÇALVES, Carlos Roberto. Direito civil brasileiro. $5^{\mathrm{a}}$ ed. São Paulo: Saraiva, 2010. p. 348349.

${ }^{12}$ NORONHA, Fernando. Direito das Obrigações. São Paulo: Saraiva, 2003. p. 587.
} 


\section{CAPÍTULO 2 - NEXO CAUSAL: PRINCIPAIS TEORIAS E SUA APLICAÇÃO PELO PODER JUDICIÁRIO}

As teorias da causalidade buscam, precipuamente, identificar, dentre todos os fatores sem os quais um determinado dano não teria ocorrido, quais deles deveriam ser compreendidos como determinantes. Em outras palavras, diante de uma série de fatores, qual contribuiu efetivamente à ocorrência do dano.

Os fatores determinantes são chamados de causa, enquanto os demais de condição. Nas palavras de NORONHA, as condições são todos os fatores:

Que estão na origem de um dano, são todos os elementos sem os quais ele não teria sido produzido, são todas circunstâncias de que não se pode abstrair, sem mudar o resultado danoso", enquanto que as causas do dano "são apenas aquelas condições consideradas como efetivamente determinantes desse resultado ${ }^{13}$.

As teorias da causalidade pretendem, portanto, estabelecer um método adequado para identificar quais condições são causas de determinado dano. À primeira vista, identificar se uma condição é determinante à produção do dano parece ser tarefa fácil, mas, como bem leciona o historiador e filósofo francês, EWALD, a situação não é tão simples quanto parece:

Essa conduta é situada, tem antecedentes; ela própria é causada; não teria produzido esse efeito sem o concurso de outros elementos. A partir do momento em que se olhe de perto, as causalidades são sempre complexas, múltiplas, entrelaçadas. Se quiséssemos segui-las a todas, não poderíamos deter-nos naquela que seria a causa do acontecimento. Para se introduzir a responsabilidade no encadeamento indefinido das causas, é preciso fazer uma escolha que, evidentemente, nada tem de natural: ela própria não tem nas coisas a sua razão, mas no juízo que delas se faz ${ }^{14}$.

\footnotetext{
${ }^{13}$ NORONHA, 2003, p. 588.
}

${ }^{14}$ EWALD, 2000, p. 169. 
Diante de tamanho desafio, três teorias formuladas para resolver o problema do nexo de causalidade se destacaram: (i) a teoria da equivalência de condições; (ii) a teoria da causalidade adequada; e (iii) a teoria da causalidade direta e imediata, na sua subteoria da necessariedade.

\subsection{Teoria da equivalência das condições}

Umas das primeiras teorias desenvolvidas foi a teoria da equivalência de condições. Segundo essa corrente, não haveria diferença entre condição e causa, de modo que o nexo causal estaria evidenciado em todos os eventos considerados condições necessárias para o dano - e daí o porquê dessa teoria ser também nomeada de conditio sine qua non.

Essa teoria, elaborada por von Buri com base nos estudos de John Stuart Mill ${ }^{15}$, parte da premissa de que todas as condições contribuíram para produzir o resultado. Em outras palavras, se diversas condições concorrem para o dano, todas têm o mesmo valor e a mesma relevância. Assim, para verificar se determinada condição é causa de um dano, deve-se realizar um processo hipotético, por meio do qual elimina-se mentalmente essa condição. Se o dano, a despeito da eliminação desta condição, ainda assim se concretizar, então ela será causa do resultado ${ }^{16}$. Nesse sentido, esclarece NORONHA:

De acordo com esta teoria, seria indiferente falar em causas ou em condições do dano. Um acontecimento deveria ser considerado causa do dano sempre que se pudesse afirmar que este não teria acontecido se aquele não tivesse ocorrido: todas as condiciones sine quibus non ("condições sem as quais não") do resultado seriam causas deste ${ }^{17}$.

Essa teoria serviu de substrato fundamental à causalidade no Direito Penal, tendo se estabelecido, no art. 13 do Decreto-Lei $n^{\circ}$ 2.848/1940 (Código Penal), que "[o] resultado, de que depende a existência do crime,

${ }^{15}$ CRUZ, Gisela Sampaio da. O Problema do Nexo Causal na Responsabilidade Civil. Rio de Janeiro: Renovar, 2005. p. 37.

${ }^{16}$ CAVALIERI FILHO, 2014, p. 64.

${ }^{17}$ NORONHA, 2003, p. 589. 
só é imputável a quem lhe deu causa. Considera-se causa a ação ou omissão sem a qual o resultado não teria ocorrido". No âmbito da responsabilização penal, a teoria da equivalência das condições revela-se inofensiva, afinal, nesta seara, além do nexo causal, existem dois importantes filtros, os quais restringem consideravelmente o número de eventos que podem ser enquadrados como causa do dano: o tipo penal e o dolo.

De todo modo, mesmo diante de seu menor potencial ofensivo na esfera penal, a referida teoria aparenta ter sido abandonada pelas novas alterações legislativas no Direito Penal. Isso porque, com a introdução do $\S 1^{\circ}$ do art. 13 do Código Penal, estabeleceu-se que "a superveniência de causa relativamente independente exclui a imputação, quando, por si só, produziu o resultado". Desse modo, admite-se que, mesmo tendo a participação de determinada pessoa contribuído para o resultado, pode a mesma não ser tida como causa, se outro fator posterior, relativamente independente, produzir o dano ${ }^{18}$.

Por outro lado, na responsabilidade civil, em que as condutas ilícitas não são tipificadas, a adoção desta teoria levaria à indevida expansão do dever de reparar. Na esfera da responsabilidade civil subjetiva, haveria ainda o filtro da culpa como barreira à responsabilização de uma pessoa. $\mathrm{O}$ mesmo não pode se dizer da responsabilidade civil objetiva, em que, sendo irrelevante o elemento da culpa, ficaríamos desprovidos da capacidade de determinar a extensão dos fatos que geram danos indenizáveis ${ }^{19}$.

Para melhor demonstrar os problemas desta teoria à responsabilidade civil, veja-se o seguinte exemplo: "A" fere "B" com um arranhão. "B", a fim de fazer um curativo no arranhão, dirige-se a um hospital. Nele, "B" contrai uma infecção que o leva a morte. Neste exemplo, se aplicada a teoria da equivalência das condições, "A" também seria responsabilizado, junto com o hospital, pela morte de "B", afinal, se " $A$ " não tivesse ferido

${ }^{18}$ NORONHA, 2003, p. 591.

${ }^{19}$ Ibid., p. 591. 
"B", este não teria ido ao hospital, e, portanto, não teria contraído a infecção que lhe acometeu a morte ${ }^{20}$.

As injustiças promovidas pela teoria da equivalência das condições fizeram com que diversos autores a criticassem duramente. Dentre eles, destaquem-se as críticas de MELO DA SILVA e SCHREIBER:

De fato: a teoria da equivalência das condições, pela nenhuma restrição à ampla regra do estabelecimento da relação de causa e efeito entre condições necessariamente dependentes uma das outras, embora lógica, pode conduzir a resultados aberrantes dentro do direito. [...] Na hipótese de um homicídio, como bem lembrado por Nelson Hungria, poderia fazer-se estender, segundo tal teoria, a responsabilidade pelo evento danoso ao próprio fabricante da arma com a qual o dano se perpetrou ${ }^{21}$.

O retumbante inconveniente de sua aplicação está em ampliar ilimitadamente o dever de reparar, imputando-o a uma multiplicidade de agentes e eventos que, apenas remotamente, se relacionam ao dano produzido sobre a vítima. Com razão já se afirmou que a adoção da teoria da equivalência das condições em âmbito civil tornaria cada homem responsável por todas as desgraças que atingem a humanidade ${ }^{22}$.

Por essas incongruências, a aplicação da teoria da equivalência das condições à responsabilidade civil não vingou no ordenamento jurídico brasileiro, e tampouco nos sistemas jurídicos estrangeiros.

\subsection{Teoria da causalidade adequada}

A teoria da causalidade adequada, criada por Lidwig Von Bar, e desenvolvida por Johannes Von Kries, buscou solucionar algumas das diversas inconsistências apresentadas pela teoria da equivalência das

\footnotetext{
${ }^{20}$ Em igual sentido, veja-se o exemplo citado por Mário Júlio de Almeida Costa, em sua obra Direito das Obrigações: Facilmente se reconhecem, todavia, as manifestar injustiças a que pode conduzir a aplicação da teoria da equivalência das condições. Pense-se, por exemplo, no caso de uma pessoa ferir outra ligeiramente e esta vir a morrer no hospital, aonde se deslocou para simples curativo, em consequência de incêndio nele ocorrido.

ALMEIDA COSTA, Mário Júlio de. Direito das Obrigações. $6^{a}$ ed. Coimbra: Almedina, 1994. p. 653.

${ }^{21}$ MELO DA SILVA, Wilson. Dano Moral. In: Enciclopédia Saraiva do Direito. São Paulo: Saraiva, v. 22, 1977. p. 116.

${ }^{22}$ SCHREIBER, 2007, p. 53.
} 
condições. Para tanto, acrescentou o elemento da adequação (ou previsibilidade). Sobre o tema, LEITÃO:

\begin{abstract}
Em qualquer caso, essa teoria encontra-se subjacente ao art. $563 .^{\circ}$ do nosso Código Civil. Efectivamente, o art. 563. ${ }^{\circ}$ vem procurar resolver a questão do nexo de causalidade ao referir que "a obrigação de indemnização só existe em relação aos danos que o lesado provavelmente não teria sofrido se não fosse a lesão". Esta formulação parte da teoria da conditio sine qua non, em termos tais que até poderíamos dizer que a consagraria. No entanto, a introdução do advérbio "provavelmente" faz supor que não está em causa apenas a imprescindibilidade da condição para o desencadear do processo causal, exigindo-se ainda que essa condição, de acordo com um juízo de probabilidade, seja idónea a produzir um dano, o que corresponde à consagração da teoria da causalidade adequada ${ }^{23}$.
\end{abstract}

Dessa forma, para os adeptos dessa corrente ${ }^{24}$, o fato determinante do dano é aquele não apenas sem o qual não se teria produzido o resultado, mas também aquele cuja verificação seja adequada e previsível. Nas palavras de ALVIM, deve o fato ser "próprio a produzir um tal dano, de modo que, se não o autor do fato, mas qualquer terceiro, julgando segundo o curso ordinário das coisas, e com pleno conhecimento dos acontecimentos, teria tido a possibilidade de prever o dano"25. Consequentemente, não será adequado o fato, e, portanto, não existirá responsabilidade, quando "o dano se produz por fôrça de um concurso de circunstâncias excepcionais e fora da experiência da vida" ${ }^{26}$.

Para determinar se o dano seria (ou não) consequência normalmente previsível de determinado fato, a teoria da causalidade adequada se utiliza da prognose retrospectiva. Trata-se de exercício por meio do qual o intérprete tenta adivinhar (e, por isso, a palavra prognose), a partir de um

\footnotetext{
${ }^{23}$ LEITÃO, Luís Manuel Teles de Menezes. Direitos das Obrigações. v. I. Coimbra: Almedina, 2002. p. 325-326.

${ }^{24}$ CAVALIERI FILHO, 2014, p. 66-67;

NORONHA, 2003, p. 600;

FERREIRA DA SILVA, Jorge Cesa. Inadimplemento das Obrigações. São Paulo: Revista dos Tribunais, 2006. p. 195;

SANSEVERINO, Paulo. Princípio da Reparação Integral. São Paulo: Saraiva. p. 56-160; ALMEIDA COSTA, Mário Júlio. Direito da Obrigações. 10ª ed. Coimbra: Almedina, 2006. p. 766;

PESSOA JORGE, Fernando. Ensaio sobre os Pressupostos da Responsabilidade Civil. Coimbra: Almedina, 1999. p. 391 e ss.

${ }^{25}$ ALVIM, 1972, p. 345-346.

${ }^{26}$ Ibid., p. 345-346.
} 
determinado fato, o que pode vir a acontecer como sua consequência. Tal exercício é feito apenas após já se saber o que efetivamente aconteceu, sendo, portanto, uma análise retrospectiva. Nesse sentido, sintetiza NORONHA:

\begin{abstract}
Nesse exercício de prognose retrospectiva, o observador coloca-se no momento anterior à aquele em que o fato ocorreu e tenta prognosticar, de acordo com as regras da experiencia comum, se era normalmente previsível que o dano viesse a ocorrer. Se conclui que o dano era imprevisível, a causalidade ficará excluída. Se concluir que era previsível, como consequência do fato praticado, mesmo que estatisticamente não fosse muito provável que viesse a ocorrer, a causalidade será adequada $^{27}$.
\end{abstract}

Assim, se os efeitos abstratos do fato - auferíveis pela prognose retrospectiva - coincidirem com os efeitos concretos já verificados, existirá nexo de causalidade a ensejar a responsabilidade do autor daquele fato. Para exemplificar o que ora se aduz, veja-se as lições esclarecedoras de ALVIM:

\begin{abstract}
CARDOSO DE GOUVEIA (ob. cit., n. ${ }^{\circ}$ 69), fundado em MARTREAU e a ENDEMANN apresenta êste exemplo: "A deu uma pancada ligeira no crânio de B, a qual seria insuficiente para causar o menor ferimento, num indivíduo normalmente constituído, mas que causou a $\mathrm{B}$, que tinha uma fraqueza particular dos ossos do crânio, uma fratura de que resultou a morte. O prejuízo deu-se apesar de o fato ilícito praticado por A não ser causa adequada a produzir aquêle dano em um homem adulto".
\end{abstract}

E o autor conclui que, segundo a teoria da equivalência das condições, a pancada é uma condição sine qua non do prejuízo causado, pelo qual o seu autor terá que responder.

Contràriamente, não haveria responsabilidade, em face de teoria da causalidade $\operatorname{adequada}^{28}$.

Dessa maneira, se aplicada a teoria da causalidade adequada ao exemplo exposto no subcapítulo anterior, em que tratamos da teoria da equivalência das condições, veríamos que "A" não seria responsável pela morte de "B", pois, ainda que o arranhão tenha o levado ao hospital, onde "B” contraiu a infecção que resultou no seu falecimento, o simples arranhão

\footnotetext{
${ }^{27}$ NORONHA, 2003, p. 600-601.
}

${ }^{28}$ ALVIM, 1972, p. 345-346. 
não seria um fato adequado, ou sequer previsível, para produzir aquele resultado.

Não obstante o mérito desta teoria em prover um meio razoável de se limitar a infinita série dos antecedentes causais - como defende a teoria da equivalência das condições -, não passou ela ilesa às críticas de alguns estudiosos. Grande parte das críticas se voltaram ao caráter filosófico, à complexidade e à imprecisão da teoria, os quais comprometem a sua aplicação prática. Para demonstrar a imprecisão da teoria, António Menezes Cordeiro elabora exemplo célebre, o qual é muito bem explorado por CRUZ:

\begin{abstract}
No entendimento de António Menezes Cordeiro, a fórmula da adequação, se bem se atentar, é pouco explicativa, pois "em abastracto, são viáveis as mais diversas causas, tudo dependendo dos dados que se acrescentem", o que esclarece com o seguinte exemplo: o agente A atinge a vítima B, no peito, com um tiro; B morre: há relação de causalidade, uma vez que o disparo no peito é causa adequada de morte. Mas se, em vez disso, A apenas deixasse cair os óculo no chão e B, em consequência do susto, morresse: não haveria causalidade, por falta de adequação; contudo, se $\mathrm{A}$, herdeiro de $\mathrm{B}$ e conhecedor de sua insuficiência cardíaca, "agravada por grande sensibilidade ao inesperado", deixa cair os óculo de propósito, na tentativa de matar $\mathrm{B}$ que, de fato, morre, já haverá responsabilidade. "E adequação? Se a resposta for positiva, veremos que a fórmula da 'adequação' já não é tão bitola de coisa nenhuma: trata-se, apenas, dum espaço que iremos preenchendo com base no senso comum e em juízos de tipo ético, até que a ciência do Direito seja capaz de explicar o fenômeno". Além disso, acrescenta que a adequação depara com uma série de dificuldades perante normas de proteção e tutelas indiretas ${ }^{29}$.
\end{abstract}

Diferentemente da teoria da equivalência das condições, a teoria da causalidade adequada resistiu às críticas, sendo adotada no ordenamento jurídico de diversos países ${ }^{30}$. Há, inclusive, quem diga que essa teoria foi positivada pelo nosso ordenamento jurídico. Tal discussão será melhor explorada quando tratarmos da aplicação das teorias da causalidade pela jurisprudência pátria.

\footnotetext{
${ }^{29}$ CRUZ, 2005, p. 82.

${ }^{30}$ Ibid., p. 83-85.
} 


\subsection{Teoria da causalidade necessária}

A teoria da causalidade necessária é, na verdade, a escola mais aceita para explicar a teoria do dano direto e imediato, segundo o qual apenas serão indenizáveis aqueles danos que são consequência direta e imediata de determinado fato. A teoria do dano direto e imediato (ou nexo causal direto e imediato) foi expressamente adotada pelo nosso ordenamento jurídico, no art. 403 do Código Civil:

Art. 403. Ainda que a inexecução resulte de dolo do devedor, as perdas e danos só incluem os prejuízos efetivos e os lucros cessantes por efeito dela direto e imediato, sem prejuízo do disposto na lei processual.

Antes de abordarmos a importância desta teoria, cumpre destacarmos que, embora seja tal dispositivo alocado na parte de responsabilidade civil contratual, utilizando-se, inclusive, do termo inexecução, a doutrina é pacífica no sentido de que o mesmo deve ser estendido à responsabilidade extracontratual $^{31}$. A respeito deste entendimento, SCHREIBER explica:

Não obstante o termo inexecução, a consolidada interpretação do dispositivo da codificação anterior já estendia sua incidência também à responsabilidade extracontratual. Plena, portanto, a adoção legislativa da teoria da causalidade direta e imediata como definidora do nexo causal no direito brasileiro, seja no âmbito contratual, seja no extracontratual ${ }^{32}$.

Feito esse breve esclarecimento, retomemos os comentários acerca da importância da teoria do nexo causal direto e imediato. Pela leitura do artigo supracitado, identifica-se que essa teoria forneceu critérios mais objetivos e concretos à verificação do dever de reparar. Isso porque apenas será indenizável o resultado direto e imediato da causa. Removeu-se, portanto, os critérios abstratos e indefinidos da teoria da causalidade adequada.

${ }^{31}$ CAVALIERI FILHO, 2014, p. 31; LEITÃO, 2002, p. 330.
${ }^{32}$ SCHREIBER, 2007, p. 56-57, 
A objetificação promovida pela teoria do dano direto e imediato não trouxe apenas soluções. Para muitos, a interpretação literal dos termos "direto" e "imediato" conduzia a um filtro de ressarcibilidade demasiadamente rígido - excluindo-se sempre os danos indiretos e remotos das indenizações -, o qual gerava enorme injustiça.

Diante disso, desenvolveu-se a teoria da causalidade necessária, cujo principal expoente, Robert Joseph Pothier, sustentou serem as expressões "dano direto" e "imediato" sinônimos que revelam um liame de necessariedade, e não de simples proximidade. Sobre o desenvolvimento desta subteoria, recorra-se às sempre esclarecedoras lições de SCHREIBER:

\begin{abstract}
Com efeito, embora em sua acepção original a expressão causalidade "direta $e$ imediata" excluísse a ressarcibilidade do chamado dano indireto ou remoto, resultando em um potente filtro de ressarcibilidade, tal abordagem gerava, em certos casos, enorme injustiça. Desenvolveu-se, deste modo, no âmbito da própria teoria da causalidade direta e imediata, a chamada subteoria da necessariedade causal, que entende que as expressões dano direto e dano imediato de forma substancial, como reveladoras de um liame de necessariedade - e não de simples proximidade - entre a causa e o efeito. Haverá, assim, dever de reparar, quando o evento danoso for efeito necessário de determinada causa
\end{abstract}

Desta forma, podem-se identificar danos indiretos, passíveis de ressarcimento, desde que sejam consequência necessária da conduta tomada como causa. De fato, a melhor doutrina conclui, atualmente, que a necessariedade consiste no verdadeiro núcleo da teoria da causalidade direta e imediata, não se excluindo a ressarcibilidade excepcional de danos indiretos, quando derivados necessariamente da causa em questão ${ }^{33}$.

Para expor os seus fundamentos, Pothier elaborou o exemplo célebre do negociante que vende uma vaca, sabendo ser ela portadora de doença contagiosa. Após a negociação, a vaca veio a falecer. Antes de falecer, contudo, a vaca contaminou o restante do gado, que também morreu. Assim, sem animais para lavrar e adubar as terras, o comprador não plantou, e, por isso, não colheu. Diante da impossibilidade de pagar as suas dívidas, viu a fazenda ser executada e vendida judicialmente.

\footnotetext{
${ }^{33}$ SCHREIBER, 2007, p. 57-58.
} 
Para Pothier, o comprador apenas poderia ser indenizado pela morte de seu gado, mas não pela improdutividade de seu solo, e muito menos pela perda de sua fazenda. Isso porque, em sua visão, a comercialização de uma vaca contaminada não é causa necessária da improdutividade do solo e da venda judicial da fazenda. Com efeito, poderia o comprador comprar ou tomar por arrendamento novos bois para cultivar suas terras ou, ainda, arrendar as terras para que um terceiro as explorasse ${ }^{34}$. Comentando sobre a intenção de Pothier com esse exemplo, NORONHA:

Com o exemplo, Pothier pretendia demonstrar que o negociante não era obrigado a reparar os danos que fossem "consequência distante e indireta do dolo" com que tinha procedido; acrescentava que a regra a seguir neste caso (que era, devido à existência de dolo, a hipótese em que a indenização tinha amplitude máxima, no direito francês) devia ser a seguinte: "somente não se deve incluir nas perdas e danos, pelas quais um devedor é responsável por motivo de dolo, aqueles danos que são uma consequência distante, e que não são uma consequência necessária, pois eles podem ter outras causas". Assim, prosseguia, "o comerciante não será responsável por motivo de dolo, aqueles danos que são uma consequência distante de seu dolo e não uma relação necessária, porque, mesmo que a perda de meu gado, causada por seu dolo, tenha influenciado no desequilíbrio de meus bens, esse desequilíbrio pode ter outras causas [2002, p.148-9 ${ }^{35}$.

Vê-se que, nesse exemplo, não há grande distância entre o efeito e a causa, mas, mesmo assim, entendeu-se pela não responsabilidade do comerciante, sob o fundamento de que tais danos não seriam necessariamente consequência da venda da vaca contaminada.

Trata-se, portanto, de uma questão de necessariedade, e não proximidade. O que importa é a inexistência de outras causas capazes de justificarem aquele dano. Se, inobstante a distância entre determinado evento e dano, aquele fato for a única causa responsável por aquele dano, é evidente que estará o lesado legitimado a pleitear indenização ${ }^{36}$. Como bem assinalado por ALVIM, parte da doutrina estrangeira defende igual entendimento em seus respectivos países:

\footnotetext{
${ }^{34}$ ALVIM, 1972, p. 360-362.

${ }^{35}$ NORONHA, 2003, p. 594-595.

36 "Assim, é indenizável todo o dano que se filia a uma causa, ainda que remota, desde que ela lhe seja causa necessária, por não existir outra que explique o mesmo dano.”.

ALVIM, op. cit., p. 356-357.
} 
[comentando sobre o Código Civil espanhol] Um dos mais modernos e abalizados expositores dêste Código relaciona a idéia de necessariedade com a de inexistência de concausas: "Isto quer dizer que no inadimplemento derivado de dolo o devedor responde pelos danos que são consequência necessária do inadimplemento, mas não dos originados de outras consequências não necessárias, de mera ocasião, nem tampouco dos originados de ato do credor; em suma, excluem-se os danos ulteriores, oriundos de novas causas, sempre que estas não sejam efeito imediato e direto do inadimplemento da obrigação." (cf. Valverde y Valverde, Tratado de Derecho Civil Español, vol. II, pág. 109. Os grifos são do original).

[comentando sobre o Código Civil argentino] Por tudo isso é que OLEGÁRIO MACHADO, comentando o art. 554, reporta-se ao art. 935 e fornece um exemplo do qual se vê que a necessariedade e imediatidade o que requerem é a exclusão de concausas $^{37}$.

Entendemos, assim como os adeptos da teoria de Pothier, que o conceito de "dano direto e imediato" deve ser interpretado como sinônimo de necessariedade, pois somente assim será possível, de um lado, conferir critérios objetivos para a identificação de danos indenizáveis, e, de outro, resguardar a ressarcibilidade de danos indiretos e remotos.

\subsection{Jurisprudência brasileira: uma aplicação confusa das teorias da causalidade}

As teorias da causalidade são, como observado no capítulo anterior, extremamente complexas e, por vezes, confusas. DIREITO e CAVALIERI vão além, sustentando que "nenhuma teoria oferece soluções prontas $e$ acabadas para todos os problemas envolvendo nexo causal"38.

De fato, em situações de multiplicidade de causas, a responsabilização pelo dano torna-se tarefa extremamente difícil. Isso porque, como bem observa NORONHA, saber qual causa é a necessária para o dano depende "até do ponto de vista do observador, que tenderá a

\footnotetext{
${ }^{37}$ ALVIM, 1972, p. 367-368.

38 DIREITO, Carlos Alberto Menezes; FILHO, Sérgio Cavalieri. Comentários ao novo Código Civil. TEIXEIRA, Sálvio de Figueiredo (Coord.). v. 13, t. II, Rio de Janeiro: Forense, 2004. p. 79.
} 
considerar como causa aquela condição que por qualquer título repute mais importante" 39 . Para melhor ilustrar a complexidade desta avaliação, consulte-se o exemplo categórico, elaborado pelo jurista português Manuel de Andrade, e comentado por NORONHA:

O Mestre coimbrão exemplificava com o caso de um casal que se dá mal. Por causa das desinteligências com a mulher, uma noite o marido chega em casa embriagado. A mulher vitupera a sua conduta, ele exalta-se, pega uma pistola e dispara, ferindo-a, mas não gravemente. A mulher procura um curandeiro, o ferimento infecciona e ela acaba morrendo, quando se teria salvo, se tivesse tido assistência médica. Qual a causa da morte? Um médico poderia sustentar que era o curandeirismo, um apóstolo do antialcoolismo diria que foram as bebidas alcoólicas, uma pacifista diria que era a facilidade de as pessoas terem armas de fogo, um reformador social diria que era a inexistência de boas leis sobre o divórcio... ${ }^{40}$.

E, com base nesse exemplo, conclui corretamente o ilustre jurista brasileiro:

Não admira que a jurisprudência, quando procura encontrar nelas algum apoio, muitas vezes acabe decidindo simplesmente de acordo com o bom senso e com a invocação apenas da expressão literal condita no art. 403: quando acha um dano deve ser reparado, dirá que ele é "dano direto e imediato"; quando entende que não é merecedor de reparação, considerá-lo-á "dano indireto" 41 .

De uma forma geral, é exatamente isso que se verifica na jurisprudência brasileira. Não se sabe precisamente qual das teorias o ordenamento jurídico brasileiro adotou. Parte da doutrina, com base na redação dos artigos 944 e 945 do Código Civil e no Enunciado n ${ }^{\circ} 47$ do Conselho da Justiça Federal, afirma ter o Brasil adotado a teoria da causalidade adequada. De outro lado, temos aqueles que, com fundamento no art. 403 do Código Civil, defendem a aplicação da teoria da causalidade direta e imediata, nos termos do entendimento da teoria da causalidade necessária ${ }^{42}$.

\footnotetext{
${ }^{39}$ NORONHA, 2003, p. 599.

${ }^{40}$ Ibid., p. 599-600.

${ }^{41}$ Ibid., p. 599-600.

42 FIGUEIREDO, Luciano; FIGUEIREDO, Roberto. Direito Civil: Direito das Obrigações e Responsabilidade Civil. Salvador: JusPodivm, 2015. p. 373-374.
} 
Diante de tamanha incerteza, esperava-se que o Poder Judiciário pudesse jogar uma pá de cal nessa discussão, pronunciando-se, definitivamente, sobre qual teoria aplicar.

No entanto, não é o que acontece. Muito pelo contrário, a jurisprudência é assaz confusa no que tange ao nexo causal ${ }^{43}$. Na prática, o que se observa é que não há previsibilidade, ou tampouco segurança jurídica, nas decisões que envolvem a aplicação das teorias da causalidade. Nesse sentido, veja-se a legítima preocupação manifestada por SCHREIBER:

Em que pese a inegável importância do debate acadêmico em torno das diversas teorias da causalidade, em nenhuma parte alcançou-se um consenso significativo em torno da matéria. A observação das decisões judiciais revela que as cortes têm empregado ora uma teoria, ora outra, sem que se possa definir sequer um padrão de julgamento a partir dos diversos precedentes emitidos em um determinado ordenamento.

\section{(...)}

A posição claramente adotada pelo Supremo Tribunal Federal a favor da teoria do dano direto e imediato (necessário) não impediu que, por todo o país, proliferassem, como continuam proliferando, decisões expressamente calcadas em outras teorias da causalidade. Por exemplo, diversos julgados sustentam adotar o direito civil brasileiro a teoria da equivalência das condições. Outros tantos invocam a teoria da causalidade adequada. A efetiva investigação da ratio decisória revela, todavia, que, não raro, expressões amplas como causalidade adequada e causalidade eficiente são empregadas em procedimentos racionais que refletem o uso de outras teorias, como a subteoria da necessidade.

\section{(...)}

Com efeito, frequentemente as próprias decisões deixam clara a confusão operada, referindo-se à "teoria da causa adequada adotada em sede de responsabilidade civil, também chamada de causa direta ou imediata" ou, ainda, afirmando que "de acordo com a teoria da causalidade adequada, aceita pelo direito brasileiro, toda condição necessária do dano é presumidamente causa dele, a menos que o agente demonstre (o que não foi feito) tratar-se de evento que, de modo geral ou normal, se revele indiferente à sua produção." ${ }^{44}$.

${ }^{43}$ CRUZ, 2005, p. 21.

${ }^{44}$ SCHREIBER, 2007, p. 59-61. 
Como se vê, não bastasse a incerteza quanto a qual teoria aplicar, evidencia-se, também, a aplicação incorreta das mesmas. Em outras palavras, mesmo quando se opta por aplicar, por exemplo, a teoria da causalidade adequada, confunde-se seus elementos com aqueles pertencentes à teoria da causa direta e imediata, e vice-versa. Exemplificando a aplicação atécnica das teorias da causalidade, FROTA:

Exemplifica-se esta atuação pouco técnica de tribunais brasileiros com alguns julgamentos que geraram perplexidades na comunidade jurídica. Os exemplos são de três ordens: a) ausência de explicitação de qual a teoria do nexo causal foi adotada como razão de decidir; b) utilização concomitante de duas teorias em um caso; c) alteração, sem nenhuma justificativa, da teoria usada em uma decisão contrariando decisões anteriores da mesma turma julgadora de um determinado tribunal, seja para imputar a responsabilidade reparatória ao responsável e (ou) lesante, seja para afastar tal imputação ${ }^{45}$.

Para melhor evidenciar os equívocos cometidos pelo Poder Judiciário, veja-se, abaixo, os trechos do acórdão de dois precedentes do STJ, em que a e. Corte Superior confunde a teoria da causalidade adequada com a teoria do dano direto e imediato:

\begin{abstract}
Afinal, o nosso sistema jurídico, na esfera civil, adotou como regra a teoria da causalidade adequada (CC/2002, art. 403), de maneira que, salvo exceção prevista em lei, somente responde pelo dano aquele que lhe der causa, direta e imediatamente ${ }^{46}$.
\end{abstract}

(...) vigora, no direito brasileiro, o princípio da causalidade adequada, também denominado princípio do dano direto e imediato ${ }^{47}$.

Como se observa, a jurisprudência brasileira se revela caótica no que tange à aplicação das teorias da causalidade. Isso porque, na grande maioria das vezes, as decisões são tomadas de forma intuitiva, o que, na prática, compromete a tecnicidade de suas fundamentações. Justamente por isso, diz CRUZ que a verificação do nexo de causalidade no Brasil "é feita de forma

\footnotetext{
${ }^{45}$ FROTA, 2013, p. 58-59.

${ }^{46}$ BRASIL. STJ, EREsp 605.435, Rel. para acórdão Min. Raul Araújo, 2a Seção, j. 14.09.11.

${ }^{47}$ BRASIL. STJ, REsp 325.622/RJ, Rel. Des. convocado Carlos Fernando Mathias, $4^{\mathrm{a}}$ Turma, j. 28.10.08.
} 
intuitiva e atécnica, ora sob a influência de uma escola, ora de outra" ${ }^{48}$. Segundo FROTA, decisões tomadas com base no "princípio do bom senso" representam grandes riscos ao instituto da responsabilidade civil:

Há, outrossim, uma volatilidade decisória dos tribunais brasileiros quanto à(s) teoria(s) do nexo causal para preencher o elemento causalidade para fins de imputação do dever reparatório ao responsável pelo seu cumprimento, existindo decisões atécnicas sobre o tema (Tepedino, 2001, p. 9). Tal situação é assaz preocupante pelo fato de as decisões sobre a existência do nexo causal em um caso concreto ser intuitivas, diversas vezes, e se fundarem, consciente ou inconscientemente, em um "princípio do bom senso", e não nos critérios trazidos pelas teorias relacionadas ao nexo causal. Isso pode intensificar a rasa cientificidade presente em algumas decisões judiciais sobre o assunto.

Buscando uma forma de se compreender o panorama da causalidade na jurisprudência brasileira, TEPEDINO sugere que devemos "ter em linha de conta não as designações das teorias, não raro tratadas de modo eclético ou atécnico pelas Cortes, senão a motivação que inspira as decisões (...)"49.

Ocorre que, para tanto, seria necessário compreender a motivação que, na maioria das vezes, inspira as decisões. Para SCHREIBER, a confusão da jurisprudência brasileira é devida não pelos equívocos cometidos pelos diversos Tribunais, mas sim pela verdadeira motivação do Poder Judiciário em garantir a indenização das vítimas:

Um cenário tão eclético poderia causar, em uma leitura inicial, a impressão de uma atecnia contumaz por parte das cortes brasileiras e de outras tantas que se comportam da mesma forma. Uma análise mais profunda, porém, demonstra que o caos reinante em matéria de nexo causal corresponde não a insistentes equívocos do nosso Poder Judiciário, mas a uma deliberada abordagem do problema da causalidade de modo a lhe assegurar uma solução, por assim dizer, flexível $^{50}$.

A indenização quanto às teorias da causalidade tem servido, muito mais do que a qualquer das soluções teóricas propostas, a garantir, na prática, reparação às vítimas dos danos. Os tribunais têm, por toda parte, se valido da miríade de teorias do nexo causal para justificar um juízo antecedente de responsabilização,

\footnotetext{
${ }^{48}$ CRUZ, 2005, p. 122.

49 TEPEDINO, Gustavo. Notas sobre o nexo de causalidade. Revista Trimestral de Direito Civil. Rio de Janeiro, v. 6, p. 9, Abr./Jun. 2001.

${ }^{50}$ SCHREIBER, 2007, p. 59-61.
} 
cuja finalidade consiste, quase sempre, em assegurar à vítima alguma compensação $0^{51}$.

Desse modo, até mesmo na interpretação sugerida por TEPEDINO, encontraríamos enormes dificuldades em identificar o panorama da causalidade na jurisprudência brasileira, afinal, ao que tudo indica, as decisões são mais pautadas na necessidade de se garantir a indenização das vítimas, do que na escorreita aplicação das teorias da causalidade.

De todo modo, ao que interessa o presente trabalho, basta compreender que a nossa jurisprudência se atém à aplicação da teoria da causalidade adequada e a da causalidade necessária, as quais, não raras vezes, são confundidas ou fundidas em uma única teoria.

${ }^{51}$ SCHREIBER, 2007, p. 61-63. 


\section{CAPÍTULO 3 - AS CONCAUSAS E SEUS EFEITOS NA QUANTIFICAÇÃO DA INDENIZAÇÃO}

Por vezes, no âmbito da responsabilidade civil, pode acontecer que, para a produção de um dano, concorram o fato de uma pessoa, apontada como responsável, e um acontecimento tido como caso fortuito ou força maior. Pode também ocorrer que, com o fato do responsável, concorra um fato do próprio lesado. Pode ainda acontecer de vários fatos independentes causarem, cada um, uma parte delimitada do dano total registrado. Vê-se, portanto, que um dano pode resultar tanto de um só fato - hipótese em que se estará diante de uma causa única -, ou de diversos fatos - caso em que teremos uma multiplicidade de causas, ou concorrência efetiva de causas ${ }^{52}$.

A essas situações, em que se verifica uma efetiva concorrência de causas à produção (ou agravamento) do dano, damos o nome de concausa. Para melhor conceituar esse termo, recorra-se às lições esclarecedoras de CAVALIERI:

Concausa é outra causa que, juntando-se à principal, concorre para o resultado. Ela não inicia nem interrompe o processo causal, apenas o reforça, tal como um rio menor que deságua em outro maior, aumentando-lhe o caudal.

Em outras palavras, concausas são circunstâncias que concorrem para o agravamento do dano, mas que não têm a virtude de excluir o nexo causal desencadeado pela conduta principal, nem de, por si sós, produzir o dano ${ }^{53}$.

Como se vê, o conceito de concausa é bastante amplo: toda e qualquer causa que, acrescida à causa principal, concorre para a produção do dano. Justamente por se tratar de um fenômeno de conceito amplo, as concausas possuem uma série de classificações e se encontram em inúmeras situações do dia-a-dia.

\footnotetext{
${ }^{52}$ NORONHA, 2003, p. 639.

${ }^{53}$ CAVALIERI FILHO, 2014, p. 78.
} 
Desse modo, as concausas podem ser classificadas quanto ao momento de seu surgimento, hipótese em que distinguiremos as concausas preexistentes das supervenientes ${ }^{54} \mathrm{ou}$, ainda, quanto à natureza das causas concorrentes, caso em que estarão em posições antagônicas a concorrência real e a concorrência virtual de causas ${ }^{55}$.

O estudo das concausas é de máxima importância para se compreender a forma pela qual a causalidade interfere na quantificação da indenização. Isso porque, embora a indenização seja medida pela extensão do dano, conforme prevê o art. 944 do Código Civil ${ }^{56}$, fato é que a análise da própria “extensão do dano" depende de uma avaliação do nexo causal (e, portanto, de eventuais concausas). Sobre o tema, PONTES DE MIRANDA:

Para se pensar em extensão do dano tem-se de partir do nexo causal. A indenizabilidade do dano é na medida em que ele se acha em relação à causa, ou às concausas, ou à causa de aumento. Tem-se de considerar o prejuízo que o ofendido sofreu, ou sofreu e ainda vai sofrer, e o que pode haver lucrado, bem como a sua participação nas causas do dano ou no aumento desse ${ }^{57}$.

Dessa forma, nesses casos, é o nexo causal - e não a culpa ${ }^{58}$, como se verá mais adiante -, que interfere diretamente na quantificação da indenização. Consequentemente, será igualmente relevante apurar a contribuição de cada concausa para o resultado, a fim de se aferir o grau de responsabilidade de cada um dos autores.

No presente trabalho, buscando analisar a interferência da causalidade na quantificação da indenização, compararemos os efeitos das concausas na distribuição da indenização nos casos de concorrência real e virtual de causas.

\footnotetext{
${ }^{54}$ CAVALIERI FILHO, 2014, p. 79-81.

${ }_{55}$ ANTUNES VARELA, João de Matos. Das obrigações em geral. v. I. Coimbra: Almedina, 2000. p. 922.

56 "Art. 944. A indenização mede-se pela extensão do dano."

${ }^{57}$ PONTES DE MIRANDA, 1971, p. 206.

${ }^{58}$ Admite-se, entretanto, excepcionalmente, que o grau de culpa interfira na quantificação da indenização nos casos em que haja manifesta desproporção entre este e a extensão do dano; cf. art. 944, § único, do Código Civil.
} 


\subsection{Concorrência real de causas}

A concorrência real de causas ocorre quando dois ou mais eventos contribuem efetivamente para a produção do dano. Isso se dá, por exemplo, quando um hospital deixa de atender, com a devida presteza, um acidentado que chega em estado grave, o qual, pela demora no atendimento, vem a falecer ${ }^{59}$. Nesse caso, vê-se que dois fatores contribuíram para a morte do acidentado: o acidente que o deixou em estado grave e a demora no atendimento pelo hospital.

Situação distinta é aquela em que se verifica a concorrência virtual de causas. Nessa hipótese, que será melhor explorada no subcapítulo 3.2, existem duas causas: uma real e outra virtual. A primeira é a que efetivamente produz o dano. A segunda, por sua vez, é aquela que teria produzido o mesmo dano, se a causa real não o tivesse operado. Assim, quando um sujeito arranha um carro de terceiro que, dias depois, seria totalmente destruído por um terremoto, haverá a chamada concorrência virtual de causas.

Dentre os numerosos casos de concorrência real de causas, analisaremos três: (i) o concurso entre fatos do lesado e do responsável (causa concorrente da vítima); (ii) o concurso entre fato do lesante e condições preexistentes da vítima; e (iii) o concurso entre fatos de várias pessoas (causalidades complexas).

\subsubsection{Concurso entre fatos do lesado e do responsável}

Nessa primeira modalidade de concorrência real, temos os casos em que a vítima contribui para a produção (ou agravamento) do dano. Estaremos diante da chamada "culpa concorrente quando, paralelamente à

\footnotetext{
${ }^{59}$ MARTINS-COSTA, Judith. Provocações canelenses acerca da concausalidade. In: MARTINSCOSTA, Judith. Comentários ao Código Civil. Do Inadimplemento das Obrigações. Rio de Janeiro, v. V, t. II., $2^{\mathrm{a}}$ ed, p. 502-516, Forense, 2009.
} 
conduta do agente causador do dano, há também conduta culposa da vítima" 60 .

Vê-se, portanto, que, além de duas contribuições para o dano - uma do agente e outra da vítima -, requer-se também uma simultaneidade entre ambas as condutas. Nesse sentido, veja-se as considerações tecidas pela Ministra NANCY ANDRIGHI, no julgamento do Recurso Especial $n^{\circ}$ 725.963/RJ:

\begin{abstract}
Não há, nisto, culpa concorrente. Ou, ao menos, não se pode reconhecê-la a partir dos elementos consignados no acórdão recorrido. A concorrência de culpas, como observado no recurso especial, demandaria que a causa do inadimplemento, por ato recíproco das partes, derivasse do mesmo evento. Se há sucessividade no descumprimento por cada uma das partes, deve ser buscado o primeiro inadimplemento relevante do contrato e, a partir dele, reconhecer-se à contraparte o direito de opor, como matéria de defesa, a exceção de contrato não cumprido. Aliás, essa é, com alguma variação, a tese defendida no recurso especial interposto pelo Estaleiro Niterói ${ }^{61}$.
\end{abstract}

Dessa forma, estaremos diante de um caso de culpa concorrente se um motoqueiro, sem capacete, falece após uma colisão com um automóvel que o fez bater com a cabeça no asfalto. Nesse caso, a não utilização de um capacete pela vítima concorre com o acidente como concausa do dano. Isso porque, estivesse a vítima de capacete, outro poderia ter sido o resultado da colisão entre a motocicleta e o automóvel.

Em igual sentido, como já decidiu o Superior Tribunal de Justiça em diversas oportunidades ${ }^{62}$, há culpa concorrente nos casos de atropelamento de pedestre que atravessa a via férrea em vez de se utilizar das passarelas. Nesse caso, tanto a omissão da concessionária de transporte, a qual possui o dever de cercar e fiscalizar os limites da linha férrea, quanto a conduta da vítima, que assumiu o risco de cruzar em local não permitido, são responsáveis pela produção do dano.

\footnotetext{
${ }^{60}$ CAVALIERI FILHO, 2014, p. 59.

${ }^{61}$ BRASIL. STJ, REsp 725.963/RJ, Rel. Min. NANCY ANDRIGHI, $3^{\mathrm{a}}$ Turma, j. 23.02.10.

${ }^{62}$ Nesse sentido: BRASIL. STJ, EREsp 705859/SP, Rel. Min. Castro Filho, $2^{\text {a }}$ Seção, j. 13.12.06; BRASIL. STJ, AgRg no AREsp 181235/SP, Rel. Min. Luis Felipe Salomão, $4^{\mathrm{a}}$ Turma, j. 19.05.16; BRASIL. STJ, REsp 1034302/RS, Rel. Min. Nancy Andrighi, $3^{\mathrm{a}}$ Turma, j. 12.04.11.
} 
Em tais circunstâncias, o art. 945 do Código Civil determina que a indenização da vítima "será fixada tendo-se em conta a gravidade de sua culpa em confronto com a do autor do dano". Esse enunciado é duramente criticado pela doutrina ${ }^{63}$. Criticando o conteúdo do art. 947 do Projeto, atual art. 945 do Código Civil, AGUIAR DIAS:

No art. 947, volta-se a considerar a gravidade da culpa concorrente, para determinar a participação na obrigação de indenizar, quando o melhor e mais exato critério, na espécie, é o da causalidade. Não é o grau de culpa, mas o grau de participação na produção do evento danoso, reduzindo-se ou até excluindo a responsabilidade dos demais, que deve indicar a quem toca contribuir com a cota maior ou até com toda a indenização ${ }^{64}$.

Como se vê, a melhor interpretação do art. 945 do Código Civil é aquela segundo a qual a fixação da indenização deve observar o grau de contribuição de cada concausa para o dano. Ou seja, é necessário que o magistrado verifique a proporção em que cada conduta influenciou a produção do evento danoso. Nessa tarefa, será irrelevante, ao magistrado, auferir o grau de culpa dos agentes, como bem leciona CRUZ:

No confronto das respectivas responsabilidades, uma culpa leve, por vezes, é susceptível de produzir danos de muito maior extensão e relevância do que os derivados de uma culpa grave. Assim, não importa se um dos agentes atuou com dolo e o outro apenas culposamente, ou se existe diferença de grau, no plano da mera culpa, entre a conduta do ofensor e a do lesado - até porque, há muito, o Direito Civil abandonara a distinção, própria do Direito romano, entre os diversos graus de culpa. O nexo de causalidade é que desempenha, conforme observa Mário Julio de Almeida Costa, a dupla função de elemento da responsabilidade civil e de medida da obrigação de indenizar ${ }^{65}$.

A divergência quanto à interpretação do art. 945 do Código Civil decorre de um problema anterior, qual seja, a própria concepção do termo culpa concorrente. Isso porque, na essência, a concorrência é de causas e

\footnotetext{
${ }^{63}$ Nesse sentido: NORONHA, 2003, p. 644-647;

CRUZ, 2005, p. 342-344;

AGUIAR DIAS, José de. Da responsabilidade civil. v. 1, 9a ed., Rio de Janeiro: Forense, 1994. p. 38.

${ }^{64}$ Ibid., p. 38.

${ }^{65}$ CRUZ, op. cit., p. 334.
} 
não de culpas ${ }^{66}$. Esse problema foi muito bem explorado por CAVALIERI, que, estendendo a culpa concorrente aos casos de responsabilidade objetiva, concluiu:

Como falar em culpa concorrente onde não há culpa? Por esse fundamento, todavia, a tese é insustentável porque, como veremos, o problema é de concorrência de causas e não de culpas, e o nexo causal é pressuposto fundamental em qualquer espécie de responsabilidade. Entendemos, assim, que mesmo em sede de responsabilidade objetiva é possível a participação da vítima (culpa concorrente) na produção do resultado, como, de resto, a jurisprudência tem admitido em casos de responsabilidade civil no Estado ${ }^{67}$.

\section{Em igual sentido, MARTINS-COSTA:}

Com efeito, não há concorrência de culpas (tal como está, defeituosamente, no art. 945) porque se a vítima concorreu culposamente para a produção do dano ou se o aumentou não há "duas responsabilidades": o que ocorre é que "a relação de causação entre o dano e o fato pelo qual outrem é responsável é apenas a do dano causado menos aquele que se liga ao ato do ofendido". Isso significa que não se "medem culpas", mas danos, buscando-se pelas relações causais, o que explica a razão pela qual (pode haver) concorrência causal mesmo nos casos de responsabilidade sem culpa (responsabilidade objetiva), de modo a pré-diminuir (ou, mesmo, a pré-excluir) a responsabilidade do ofensor. Desse modo, "o ofensor responde, ou deixa de responder porque só até aquele ponto foi responsável, ou não foi responsável", pois, "no mundo jurídico, já acontecera a diminuição ou exclusão, de modo que não se há de pensar em qualquer operação de subtração ${ }^{68}$.

Esse é o entendimento mais razoável. Prova disso é que, nos termos do art. $12, \S 3^{\circ}$, III, do Código de Defesa do Consumidor (“CDC”), o fabricante, construtor, produtor ou importador não será responsabilizado quando provar que o dano decorreu da "culpa exclusiva do consumidor ou de terceiro".

\footnotetext{
${ }^{66}$ Há quem se refira à concorrência de causas como "concorrência de culpas". Tal equívoco, há muito, é objetado por PONTE DE MIRANDA: Preliminarmente, é de afastar-se o conceito, que turvou a investigação e perturba a discussão, ainda hoje, de compensação de culpas. Culpas não se compensam. $O$ ato do ofendido é concausa ou aumentou o dano. Trata-se de saber até onde, em se tratando de concausa, responde o agente, ou como se há de separar do importe o excesso, isto é, o que tocaria ao que fez maior o dano, que, aí, é o ofendido.

PONTES DE MIRANDA, Francisco Cavalcanti. Tratado de Direito Privado. t. XXII. Rio de Janeiro: Borsoi, 1958. p. 197-198.

${ }^{67}$ CAVALIERI FILHO, 2014, p. 60.

${ }^{68}$ MARTINS-COSTA, 2009, p.502-516.
} 
Embora a culpa exclusiva da vítima seja distinta da culpa concorrente - porquanto, na primeira, sendo uma excludente de nexo causal, exclui-se o dever de reparar do autor, enquanto na segunda, opera-se apenas a sua redução -, a presença de tal excludente no CDC revela que o termo "culpa", nesses casos, é melhor compreendido como "causa". Isso porque, naturalmente, em relações consumeristas, em que a responsabilidade civil é objetiva, não há que se falar, necessariamente, em culpa. Qualquer outra interpretação tornaria inócua a excludente prevista no art. $12, \S 3^{\circ}$, III, do CDC, afinal, sendo a responsabilidade objetiva, seria irrelevante examinar a culpa da vítima (consumidor).

Dessa forma, havendo culpa concorrente (ou melhor, causa concorrente da vítima), será necessário que o magistrado realize a redução proporcional da indenização, de modo a condenar o autor do dano apenas até o limite de sua efetiva contribuição para o resultado.

\subsubsection{Concurso entre fato do lesante e as condições preexistentes da vítima}

O concurso entre a causa de um dano e as condições preexistentes da vítima configura um exemplo típico de concausa preexistente. Nesses casos, um evento causa (ou agrava) o dano em função das condições preexistentes da vítima.

É, por exemplo, o já mencionado caso do sujeito que deu uma pancada no crânio de um indivíduo, a qual seria insuficiente para causar o menor ferimento, mas que, pelo fato do indivíduo possuir uma fraqueza particular nos ossos do crânio, lhe acarretou a morte. Nesse exemplo, sob o prisma da teoria da causalidade adequada, ALVIM concluiu não haver responsabilidade por parte do sujeito que deu a pancada ${ }^{69}$.

\footnotetext{
${ }^{69}$ ALVIM, 1972, p. 345-346.
} 
Analisando tal exemplo sob a perspectiva da teoria da causalidade necessária chegaríamos a igual conclusão. Sobre o tema, os ensinamentos de SCHREIBER:

De fato, tomando-se qualquer das teorias da causalidade, não resulta possível considerar o efeito, absolutamente imprevisível, decorrente de uma anormalidade congênita da vítima, como um efeito direto, imediato ou necessário da conduta do ofensor, nem parecer ser sua conduta a causa adequada ou eficiente do dano mais grave experimentado ${ }^{70}$.

Segundo CAVALIERI, “as condições pessoais de saúde da vítima, bem como as suas predisposições patológicas, embora agravantes do resultado, em nada diminuem a responsabilidade do agente"71. Em suas palavras, "o agente responde pelo resultado mais grave, independentemente de ter ou não conhecimento da causa antecedente que agravou o dano"72.

Esse entendimento encontra amparo na "Egg-Shell skull rule"73, doutrina desenvolvida pelos sistemas do common law, segundo a qual as fragilidades preexistentes da vítima não podem ser utilizadas como defesa para o autor do dano. No paradigmático caso Vosburg v. Putney, a Suprema Corte de Wisconsin, aplicando a referida doutrina, condenou Putney ao pagamento de indenização a Vosburg, pelo chute na canela que o primeiro deu no segundo. Em síntese, Putney deu um leve chute na canela de Vosburg, que, no momento do ato, nada sentiu. Entretanto, alguns minutos após o chute, Vosburg estava chorando de dor. Na semana seguinte, Vosburg foi levado à mesa de cirurgia, onde os médicos constataram que, em função da fragilidade causada por um acidente anterior àquele evento, o chute de Putney resultou na deterioração permanente do osso da canela de uma das pernas de Vosburg. Diante desse cenário, a Suprema Corte de Wisconsin condenou Putney ao pagamento de indenização, sob o

\footnotetext{
${ }^{70}$ SCHREIBER, 2007, p. 73.

${ }^{71}$ CAVALIERI FILHO, 2014, p. 79.

72 Ibid., p. 79.

${ }^{73}$ Tradução livre: "A Regra do Crânio de Casca de Ovo".
} 
fundamento de que, sendo o chute um ato ilícito, deve o lesante responder por todas as consequências de sua conduta, ainda que imprevisíveis ${ }^{74}$.

Em sentido contrário ao de CAVALIERI, SCHREIBER advoga pela impossibilidade de se responsabilizar o autor da pancada pelo resultado mais grave do seu ato, porquanto a "preponderância causal cabe à fragilidade congênita, e não ao comportamento do agente":

Em outras palavras, mesmo que a fragilidade intrínseca da vítima não fosse suficiente a interromper a cadeia causal, excluindo integralmente a responsabilidade do agente, o resultado mais grave, em um exame normal de preponderância, derivaria, principalmente, da condição especial do lesado. Diante de "pequeno golpe" de que "resulte fratura no crânio em razão da fragilidade congênita do osso frontal", a preponderância causal cabe à fragilidade congênita peculiar, e não ao comportamento do agente ${ }^{75}$.

Para FROTA, deverá o lesante ser responsabilizado pelo dano que causou, mas não pelo agravamento do resultado diante da condição predisposta da vítima, a menos que, sabendo de tal condição, tenha escolhido causar o dano. Nas palavras do autor, "a condição predisposta da vítima não afasta a causalidade, mas concorre para a redução do valor reparatório se tal condição agravar o dano" ${ }^{76}$.

Já para SCHREIBER, a responsabilização do lesante pelo resultado mais grave:

Consiste em fazê-lo responder por efeito que não se vincula à sua conduta, salvo por uma relação de sentido natural, correspondente à tão criticada teoria da equivalência das condições, cuja ausência de limites afigura-se perigosa em um campo do direito livre da atipicidade como é a responsabilidade civil ${ }^{77}$.

Embora concordemos com o posicionamento de SCHREIBER e FROTA, cumpre alertar que este não tem sido o entendimento da jurisprudência, como bem salientou CAVALIERI ${ }^{78}$.

\footnotetext{
${ }^{74}$ Vosburg v. Putney, 86 Wis. 278, 56 N.W. 480, 1893 Wisc. LEXIS 133 (Wis. 1893).

${ }^{75}$ SCHREIBER, 2007, p. 73.

${ }^{76}$ FROTA, 2013, p. $155-156$.

${ }^{77}$ SCHREIBER, op. cit., p. 74.

${ }^{78}$ CAVALIERI FILHO, 2014, p. 79.
} 


\subsubsection{Concurso entre fatos de várias pessoas}

Outra hipótese de concorrência real de causas é aquela na qual diversas pessoas contribuem para a verificação do dano. Nessa hipótese, como bem salienta NORONHA, será necessário distinguirmos três situações:

Se várias pessoas tiverem contribuído para a verificação do dano, praticando fatos diferentes, vai ser preciso distinguir três hipóteses; a) a da prática, por cada uma delas, de fato que só por si seria suficiente para causar todo o dano verificado; b) a da prática, por cada uma delas, de fato que só por si não seria suficiente para causar o dano, ou todo ele, mas que somado aos outros foi causa necessária dele; c) a de independente causação por cada pessoa, cada uma praticando um fato diferente, de uma parte delimitada do dano. Na primeira hipótese poderemos falar em causalidade colateral, na segunda em causalidade concorrente propriamente dita (ou co-causalidade) e na terceira em causalidade cumulativa (ou acumulativa) ${ }^{79}$.

Vê-se, portanto, que NORONHA classifica três situações distintas para os casos em que danos resultam da concorrência de fatos de várias pessoas: (i) causalidade colateral; (ii) causalidade concorrente propriamente dita; e (iii) causalidade cumulativa.

Com relação à primeira, diz o autor termos a "causalidade colateral quando existem dois ou mais fatos, atribuíveis a pessoas diferentes, que estão em situação tal que qualquer deles, sozinho, tinha força suficiente para provocar o dano" 80 . Esse é o exemplo clássico do cozinheiro e do empregado de mesa que, agindo separadamente e sem conhecimento da ação do outro, dão, cada um, ao patrão uma dose de veneno suficientemente forte para lhe provocar a morte ${ }^{81}$.

Nestes casos, em que os fatos independentes possuem a potencialidade, dentro de uma relação de causalidade adequada, para originar o dano em sua totalidade, todos os agentes serão co-autores do

\footnotetext{
${ }^{79}$ NORONHA, 2003, p. 647.

${ }^{80}$ Ibid., p. 647.

${ }^{81}$ Ibid., p. 647-648.
} 
dano e, portanto, nos termos do art. 942 , $\S$ único, do Código Civi1 ${ }^{82}$, estarão solidariamente obrigados a indenizar o lesado.

A causalidade concorrente propriamente dita, por sua vez, estará presente "quando há dois ou mais fatos independentes, nenhum com potencialidade para causa o dano verificado, ou todo este, mas que somados acabam causando-o"83. Exemplificando essa hipótese, NORONHA:

Um exemplo simples desta situação é constituído pelo caso em que dois motoristas contribuem para que um pedestre venha a ser atropelado, um deles por conduzir com excesso de velocidade e o outro por irregularmente conservar a luz alta, assim causando o encadeamento do primeiro. Outro bom exemplo é o referido por F. M. Pereira Coelho (1998, p. 32] e Manuel de Andrade [1958, p. 356], ainda que a outro propósito: uma casa que já ameaçava ruína em consequência do choque de um veículo vem a cair com o embate de outro, ou em consequência de um ciclone, tendo sido o estado de ruína provocado pelo primeiro acidente que favoreceu a eficácia causal do segundo evento.

Nesses casos, para a quantificação da indenização, aplica-se regra semelhante àquela da culpa concorrente da vítima, qual seja, a fixação de acordo com o grau de contribuição de cada concausa.

Registre-se, no entanto, que, diferentemente do concurso entre fatos do lesado e do responsável (culpa concorrente da vítima), a causalidade concorrente propriamente dita não resulta na redução do quantum indenizatório. Isso porque, naturalmente, não tendo o lesado contribuído à produção do dano, deve ele ser ressarcido pela integralidade da extensão do dano. Há, todavia, a distribuição proporcional à contribuição de cada concausa no âmbito interno da relação entre os lesantes. Foi assim que decidiu o Ministro NAPOLEÃO NUNES MAIA FILHO, no julgamento do AgInt no AgRg no AREsp 227.905/RS:

\footnotetext{
${ }^{82}$ Art. 942. Os bens do responsável pela ofensa ou violação do direito de outrem ficam sujeitos à reparação do dano causado; e, se a ofensa tiver mais de um autor, todos responderão solidariamente pela reparação.

Parágrafo único. São solidariamente responsáveis com os autores os co-autores e as pessoas designadas no art. 932.

${ }^{83}$ NORONHA, 2003, p. 649.
} 
No trecho colacionado do acórdão objurgado é induvidoso que o DNIT é responsável por uma das quatro causas do dano do imóvel e que o valor arbitrado para a reparação do dano é de $\mathrm{R} \$ 14.000,00$. Dessa forma, caberia ao Tribunal de origem dividir equitativamente a responsabilidade pela reparação do dano ou pelo menos justificar o motivo pelo qual condenou o DNIT em 100\% da indenização, o que não ocorreu no caso.

É importante ressaltar que se o dano injusto foi provocado por uma pluralidade de causas, como no caso (funcionais, endógenas, naturais e exógenas), todas as causas devem ser consideradas na determinação proporcional da indenização.

A responsabilidade civil pressupõe uma relação de causa e efeito entre o dano invocado e o fato ilícito. A concausa, como causa paralela ou concomitante, concorrendo com outra para a produção do seu efeito, não deixa de ser causa, acarretando, por isso, a obrigação de reparar o dano por parte do responsável. Em casos tais, deve essa responsabilidade ser atenuada, por força do princípio da divisão dos riscos, que se afina com a teoria da responsabilidade objetiva ${ }^{84}$.

Como se observa do julgado supracitado, não se cogitou de modificar o quantum devido ao lesado, mas tão somente a sua distribuição de acordo com o grau de contribuição de cada concausa. Justamente por isso, a $1^{\text {a }}$ Turma do Superior Tribunal de Justiça entendeu por bem em anular o acórdão recorrido, para o fim de determinar que o Tribunal a quo valorasse a contribuição de cada concausa.

Por fim, teremos a causalidade cumulativa "quando cada um dos vários responsáveis agiu independentemente e causou (em termos de causalidade adequada) uma parte delimitada do dano total"85. Um exemplo bem elucidativo foi elaborado por NORONHA:

Um exemplo simples de causalidade cumulativa é o do carro que num acidente de trânsito é embatido na ré, sendo projetado para a outra faixa de trânsito, onde fica imobilizado e onde momentos depois é colidido na frente por outro veículo, cujo condutor vinha desatento ou com excesso de velocidade ${ }^{86}$.

Nesses casos, cada agente ficará responsável pelo dano que causou. Isso porque, diferentemente da hipótese de causalidade concorrente

\footnotetext{
${ }^{84}$ BRASIL. STJ, AgInt no AgRg no AREsp 227.905/RS, Rel. Min. Napoleão Nunes Maia Filho, $1^{\text {a }}$ Turma, j. 21.08.18.

${ }^{85}$ NORONHA, 2003, p. 651-652.

${ }^{86}$ Ibid., p. 652.
} 
propriamente dita, na causalidade cumulativa é possível identificar a autoria de cada dano. No exemplo utilizado por NORONHA, percebe-se que o autor da primeira batida seria responsabilizado pelo dano gerado na ré do veículo, enquanto o agente do segundo acidente se responsabilizaria pelos danos ocasionados na parte da frente do automóvel.

A verdade é que, a despeito das particularidades de cada caso, há uma regra geral segundo a qual a distribuição do dever de indenizar deve ser proporcional à contribuição do agente para a produção do dano. Assim, revela-se pertinente a crítica de CRUZ quanto ao enunciado do art. 945 do Código Civil, pois, segundo a autora, o referido dispositivo "não se deveria referir apenas aos casos em que a vítima concorre com o agente. Melhor seria se o legislador tivesse elaborado uma regra geral de distribuição do prejuízo entre os co-responsáveis pelo dano" ${ }^{87}$.

Dessa forma, para além de fazer menção expressa ao grau contribuição do lesante à quantificação da indenização - excluindo-se as menções à culpa -, deveria o legislador ter contemplado todas as hipóteses de concorrência real de causa, e não somente a concorrência entre fatos do lesado e do responsável (culpa concorrente da vítima).

\subsection{Concorrência virtual de causas}

A concorrência virtual de causas é aquela que se opera entre uma causa real e outra virtual. A causa é real quando o dano é realmente produzido, sendo virtual quando o dano não chega a ser produzido. A distinção entre a concorrência real e virtual de causas reside justamente nesse ponto: a concorrência entre causas que produziram ou não o dano. Sobre o tema, o Supremo Tribunal de Justiça de Portugal:

É também na produção do dano que se encontra o traço distintivo entre o concurso real e o concurso virtual: só se estará em face um situação de concurso virtual se o dano for realmente produzido apenas por uma das causas (a causa

${ }^{87}$ CRUZ, 2005, p. 344. 
real) e não chegar a ser produzido apenas por uma das causas (a causa real) e não chegar a ser produzido pela outra causa (a causa virtual), já que, sendo o dano produzido por ambas as causas, o concurso será real, e não virtual ${ }^{88}$.

Em outras palavras, a causa hipotética ou virtual é aquela causa que não chegou a provocar o dano - embora fosse capaz de produzi-lo -, pelo fato deste ter sido produzido pela causa real ou operante ${ }^{89}$.

Advirta-se, desde já, que a expressão "causa hipotética", conquanto amplamente aceita pela doutrina, traduz nítida contradição terminológica, como bem destacou PEREIRA $\mathrm{COELHO}^{90}$. Isso porque, na essência, apenas é causa aquele evento que contribuiu para a produção do dano. $\mathrm{Ou}$ seja, a rigor, toda causa é necessariamente real, de modo que, sendo virtual ou hipotética, não se poderia falar causa. De todo modo, frente à tamanha aceitação deste termo pela doutrina, analisaremos a concorrência virtual nos moldes delimitados acima.

No estudo da concorrência virtual de causas, duas questões ganham maior relevo. Na primeira delas, indaga-se se é possível uma pessoa ser responsabilizada pelo dano que não causou, mas que teria causado não fosse a intervenção de outro fato. Na segunda, questiona-se se a causa virtual poderia ser invocada pelo autor da causa real para diminuir ou excluir sua obrigação de indenizar ${ }^{91}$. Em suma, o estudo da concorrência virtual de causas busca investigar se a causa virtual é dotada de relevância positiva e negativa.

No presente trabalho, nos ateremos à investigação da interferência da causa virtual na quantificação da indenização. Dito de outra forma, analisaremos se o autor da causa real pode invocar a causa virtual para diminuir a sua obrigação de indenizar. Trata-se, portanto, de um estudo sobre a relevância negativa da causa virtual.

\footnotetext{
${ }^{88}$ PORTUGAL. STJ, Processo $n^{\circ}$ 02B4369, $\mathrm{n}^{\mathrm{o}}$ do documento: SJ200302130043697, Rel. Min. Oliveira Barros, j. 13.02.2003.

${ }^{89}$ CRUZ, 2005, p. 208-213

${ }^{90}$ PEREIRA COELHO, Francisco Manuel. Coimbra: Livraria Almedina, 1998. p. 45.

${ }^{91}$ CRUZ, op. cit., p. 208-213.
} 
Para melhor evidenciar a relevância desta investigação, recorra-se aos exemplos elaborados LARENZ:

\begin{abstract}
Para resolver la cuestión expongamos dos ejemplos: A, que regresa a su casa eufórico después de pasar una tarde alegre, rompe con el bastón el cristal de la ventana de B y se declara dispuesto al siguiente día a mandar colocar a su costa un nuevo cristal; pero antes de que esto se lleve a efecto se produce en las proximidades una fuerte explosión que rompe todos los cristales de los alrededores. A sostiene entonces que $\mathrm{B}$, según ahora resulta, no fue perjudicado por él, porque si A no hubiese roto el cristal éste lo hubiera sido poco después como consecuencia de la explosión.
\end{abstract}

Segundo ejemplo: B queda inutilizado para el trabajo por un accidente del que es responsable A, que es por ello condenado al pago de una pensión alimenticia ( $\S$ 843). Más tarde B es condenado a cumplir dos años de pena privativa de libertad; A sostiene no estar obligado a pagar la pensión durante el tiempo en que B cumple condena, puesto que éste, durante dicho tiempo, hubiera permanecido $\sin$ ingresos, aunque el accidente no hubiera tenido lugar ${ }^{92}$.

Como se vê, a relevância negativa da causa virtual possui enorme importância prática. No primeiro exemplo, o autor alemão examina a possibilidade de o autor da causa operante se desonerar da obrigação de indenizar o lesado, sob o fundamento de que o vidro seria, logo em seguida, destruído por uma explosão que rompeu todos os vidros da região. No segundo, o jurista alemão examina a viabilidade de um agente, condenado ao pagamento de pensão alimentícia por um acidente que provocou na vítima, reduzir a sua obrigação pecuniária em razão da prisão da vítima pelo período de dois anos.

No primeiro caso, há de se investigar se a causa virtual exclui o nexo causal entre a conduta do lesante e o dano. Já no segundo, a questão está mais ligada à possibilidade de a causa virtual interferir na extensão da indenização. Identifica-se, portanto, as duas principais indagações acerca da relevância negativa da causa hipotética: (i) se a causa virtual é capaz de eliminar a relação de causalidade existente entre a causa operante e o dano;

\footnotetext{
${ }^{92}$ LARENZ, Karl. Derecho de Obligaciones. t. I. Madrid: Editorial Revista de Derecho Privado, 1958. p. 211.
} 
e (ii) se a causa virtual é capaz de interferir na extensão do dever de indenizar.

Antes de abordar ambos os temas, é necessário tratar, ainda que suscintamente, dos pressupostos fundamentais à investigação da relevância negativa da causa virtual. Isso porque, nas palavras de CRUZ, "o problema da relevância negativa da causa virtual exige não só que fique caracterizada a situação acima descrita - um fato provocou um dano, mas este dano seria causado por outro fato se aquele não tivesse tido lugar-, mas também a presença de outros pressupostos sem os quais o problema nem mesmo se põe $e^{, 93}$.

Em primeiro lugar, a causa real deve gerar uma obrigação de indenizar para o autor do dano. Isto é, não pode a causa real ser um caso fortuito ou força maior, afinal, em ambos os cenários, não há "autor do dano", motivo pelo qual inexiste interesse em se tratar da relevância negativa da causa virtual.

Em segundo lugar, o problema da relevância negativa da causa hipotética só se levanta em relação ao dano provocado pela causa real. Em outras palavras, não se considera os danos já sofridos pelo lesado em consequência de outros fatores. Exemplificando a importância deste pressuposto, ANTUNES VARELA:

Se a pessoa atropelada mortalmente era um doente canceroso, cuja vida estava por meses, a capacidade de trabalho que deve ser considerada na fixação da indemnização não pode deixar de tomar em conta o dano já causado pela doença, pondo-se o problema da relevância da causa virtual apenas em relação ao dano imputável à causa real ${ }^{94}$.

Em terceiro lugar, para que o problema da relevância negativa seja pertinente, é imperioso que a causa virtual seja só hipotética para o dano provocado pela causa real ${ }^{95}$. Caso contrário, se a série causal hipotética

\footnotetext{
${ }^{93}$ CRUZ, 2005, p. 216-217.

${ }^{94}$ ANTUNES VARELA, 2000, p. 922.

${ }^{95}$ CRUZ, 2005, p. 218-220.
} 
favoreceu a eficácia causal da série causal operante, não há que se falar em concorrência virtual, mas apenas em concorrência real de causas.

Por fim, é imprescindível que o dano tivesse se verificado, mesmo sem a causal real, por força da causa hipotética. Vale dizer: a causa virtual deve ser aquela que teria produzido o dano se não fosse o surgimento da causa real. Desse modo, no exemplo elaborado por ANTUNES VARELA ${ }^{96}$, em que o lavrador se queixa de que o vizinho teria lhe inutilizado culposamente uma parte de sua plantação de tomates, o qual, em sua defesa, sustenta que uma tromba de água, que passaria poucos dias depois, teria destruído todas as plantações da região, é essencial que o vizinho comprove que os tomates do lavrador não seriam comercializados antes de a tromba de água assolar a região.

Introduzidos os pressupostos à aferição da relevância negativa da causa virtual, procederemos à análise dos comentários da doutrina sobre a possibilidade de autor da causa real suscitar a causa virtual como excludente ou atenuante de sua responsabilidade pelo dano.

NORONHA parte da própria definição de causa hipotética para concluir pela irrelevância negativa da causa virtual. Em sua concepção, "se a causa virtual poderia ter ocasionado o dano, o certo é que não foi ela que o causou efetivamente" 97 . A partir desta constatação, conclui não ter a causa virtual relevância negativa, pois, não sendo ela capaz de estabelecer um nexo causal com o dano, permanece hígido o nexo causal existente entre a causa real e o resultado danoso.

Em igual sentido, opina ALMEIDA COSTA, segundo o qual:

A causalidade virtual não possui relevância negativa de excluí-la [a causa real], pois em nada afecta o nexo causal entre o facto operante e o dano" ${ }^{98}$, de modo

\footnotetext{
${ }^{96}$ ANTUNES VARELA, 2000, p. 922.

${ }^{97}$ NORONHA, 2003, p. 658-659.

${ }^{98}$ ALMEIDA COSTA, 1994, p. 660-661.
} 
que "sem o facto operante o lesado teria um dano idêntico, mas não aquele preciso dano".

Ademais, se encararmos a relevância positiva e negativa da causa virtual como dois lados de uma mesma moeda, como sugere CRUZ ${ }^{100}$, tornam-se relevantes as considerações tecidas por LEITÃO. Para o autor, se aceitássemos a relevância positiva da causa virtual, estaríamos responsabilizando o autor da causa hipotética "por danos que não resultaram do seu comportamento" ${ }^{101}$. Em outras palavras, o direito estaria chancelando a responsabilidade civil desprovida de nexo causal. Algo incogitável, como vimos até agora neste trabalho.

Para PEREIRA COELHO, a causa virtual também não teria relevância negativa, pois, em sua opinião, o dever de indenizar "não visa então reparar o dano, pois não há aí um dano como diferença no patrimônio, mas sancionar e prevenir violações de direitos ou de bens juridicamente protegidos" 102 . Assim, o importante é que o agente tenha cometido um ato ilícito, por meio do qual produziu um dano. Isso, per se, justificaria o dever do lesante de indenizar a vítima, sendo irrelevante a possibilidade daquele dano ter sido produzido por uma causa virtual.

Pautando-se em todas essas opiniões, CRUZ é precisa ao concluir que "a doutrina, atualmente, é pacífica ao afirmar que a causa virtual não exclui a relação de causalidade que liga a causa operante ao dano"103. Sem dúvidas, não nos parece ser possível atribuir à causa virtual o condão de excluir o nexo causal ao ponto de o autor da causa operante se desonerar da obrigação de indenizar.

\footnotetext{
${ }^{99}$ ALMEIDA COSTA, 1994, p. 660-661.

100 “'Causalidade interrompida' e 'causalidade antecipada' representam, em realidade, dois lados de uma mesma moeda: aquela diz respeito ao problema da relevância positiva da causa virtual; enquanto esta trata do problema inverso, isto é, da relevância negativa da causa virtual.". CRUZ, 2005, p. 211-212.

${ }^{101}$ LEITÃO, 2002, p. 327-328.

102 PEREIRA COELHO, Francisco Manuel. O problema da causa virtual na responsabilidade civil. Coimbra: Livraria Almedina, 1998. p. 5.

${ }^{103}$ CRUZ, 2005, p. 248-250.
} 
Essa, contudo, como veremos a seguir, é a regra geral, pois, em algumas circunstâncias, o próprio Código Civil prevê hipóteses restritas de aceitação da relevância negativa da causa virtual. Exemplos da exceção à regra geral da irrelevância negativa da causa virtual podem ser vistos nos arts. 399; 667, $§ 1^{\circ} ; 862$ e 1.218 do Código Civil:

Art. 399. O devedor em mora responde pela impossibilidade da prestação, embora essa impossibilidade resulte de caso fortuito ou de força maior, se estes ocorrerem durante o atraso; salvo se provar isenção de culpa, ou que o dano sobreviria ainda quando a obrigação fosse oportunamente desempenhada.

Art. 667. (...) $\S 1^{\circ}$. Se, não obstante proibição do mandante, o mandatário se fizer substituir na execução do mandato, responderá ao seu constituinte pelos prejuízos ocorridos sob a gerência do substituto, embora provenientes de caso fortuito, salvo provando que o caso teria sobrevindo, ainda que não tivesse havido substabelecimento.

Art. 862. Se a gestão foi iniciada contra a vontade manifesta ou presumível do interessado, responderá o gestor até pelos casos fortuitos, não provando que teriam sobrevindo, ainda quando se houvesse abatido.

Art. 1.218. O possuidor de má-fé responde pela perda, ou deterioração da coisa, ainda que acidentais, salvo se provar que de igual modo se teriam dado, estando ela na posse do reivindicante.

A doutrina brasileira tardou a reconhecer a recepção da relevância negativa da causa virtual pelo nosso Código Civil. Nas hipóteses dos dispositivos acima citados, tanto o devedor, como o mandatário, o gestor e o possuidor estão em posições agravadas, estando sujeitos, inclusive, à responsabilização por acidentes fortuitos - o que constitui uma exceção à regra do art. 393 do Código Civil $^{104}$.

Nesses casos, identifica-se uma presunção relativa de causalidade. Em outras palavras, o devedor, o mandatário, o gestor e o possuidor apenas se eximem da responsabilidade por danos oriundos de casos fortuitos se comprovarem que o dano sobreviria ainda que cumprida as suas respectivas obrigações. A doutrina brasileira limita-se a afirmar que a desoneração da

104 “Art. 393. O devedor não responde pelos prejuízos resultantes de caso fortuito ou força maior, se expressamente não se houver por eles responsabilizado.” 
responsabilidade ocorre porque se comprova que não há nexo causal entre a mora do devedor e o dano, como também não há entre a desobediência dos obrigados e o dano ${ }^{105}$. Nesse sentido, NORONHA:

Poderia parecer que nestes casos o Código Civil reconhece relevância à causa virtual, para excluir a obrigação de indenizar. Cremos, porém, que nestas situações o que acontece é a posse de má-fé, a mora ou a gestão prohibente domino inverterem o ônus da prova do nexo de causalidade entre o fato do responsável (posse, mora, gestão) e o dano.

\begin{abstract}
Nestas hipóteses, a verdadeira causa do dano é um caso fortuito, independente do fato atribuível ao indigitado responsável. Com mais precisão poder-se-ia dizer que o caso fortuito é, aqui, a causa real do dano. E o que importa saber é se o fortuito é causa independente do dano, ou se ele é mera consequência (adequada) do fato que é da responsabilidade do indigitado - posse de má-fé, mora no adimplemento, gestão prohibente domino. Por outras palavras, a questão está em saber se o caso fortuito aconteceu devido ao fato de a coisa estar em mãos diferentes daquelas em que devia estar. Ora, nestes casos a lei presume isto mesmo, presume que o fortuito não teria acontecido se não fosse o fato da posse, ou da mora, ou da gestão ${ }^{106}$.
\end{abstract}

Para CRUZ, no entanto, tal explicação não é satisfatória. Desse modo, a insuficiência da explicação fornecida por parte da doutrina brasileira está no fato de que esta não contempla a hipótese de o devedor em mora conseguir comprovar que, ainda que ele tivesse cumprido a obrigação a tempo, o dano teria sobrevindo em razão de outra causa, distinta da que produziu o dano em concreto. Nas palavras da autora, " $a$ parte final do art. 399 do Código Civil deve valer tanto para o caso em que a causa hipotética é o mesmo fortuito, como para a hipótese em que ela é outro fato, diferente daquele que atingiu efetivamente o objeto nas mãos do obrigado a indenizar" ${ }^{107}$. A autora sugere que se interprete esse dispositivo à luz da relevância negativa da causa virtual e, para tanto, expõe o seguinte exemplo:

Suponha-se que, no período de mora do devedor, a coisa que ele deve entregar ao credor pereça, em razão de um incêndio que atinge o local onde o devedor guardava a coisa (ex.: sítio do devedor). Ao ser demandado pelo credor, consegue

\footnotetext{
105 CRUZ, 2005, p. 252.

106 NORONHA, 2003, p. 588.

${ }^{107}$ CRUZ, op. cit., p. 253-254.
} 
o devedor provar que, ainda que ele tivesse cumprido sua obrigação no prazo aventado, o dano sobreviria, porque o local onde o credor guardaria a coisa (ex.: sítio do credor) também fora reduzido a cinzas, em virtude de uma explosão que ocorrera nas proximidades. Neste exemplo, a explosão é a causa virtual do dano; enquanto o primeiro incêndio, a causa operante. $\mathrm{O}$ devedor não deverá responder - diria a doutrina portuguesa -, porque o art. 399 do Código Civil brasileiro confere, expressamente, relevância negativa à causa virtual nessa hipótese, e não simplesmente porque falta nexo causal entre a mora do devedor e o dano ${ }^{108}$.

Esse entendimento está em consonância com os ensinamentos de PEREIRA COELHO, o qual expôs igual conclusão ao comentar sobre dispositivos semelhantes constantes do Código Civil português:

\begin{abstract}
A ratio legis destes preceitos, enquanto dão relevo à causa virtual, não estará, pois, só em que não há dano - em que não há diferença - quando o proprietário ou o dominus teriam igualmente sofrido o dano sem a posse ou sem a gestão, mas também em que o possuidor e o gestor respondem aqui por um dano acidental, que provém de uma causa que não lhes é imputável. Presumindo que esta causa não se teria verificado se não fosse o seu facto, a lei responsabiliza-os por aquele dano; mas a responsabilidade por um dano acidental, aos olhos da lei, significa um agravamento da esfera norma da sua responsabilidade; e por isso a lei permite ao possuidor e ao gestor a invocação de uma causa hipotética que teria igualmente produzido o dano acidental por que os torna responsáveis ${ }^{109}$.
\end{abstract}

No que tange à excepcionalidade da relevância negativa da causa virtual, LEITÃO é enfático ao afirmar que, com a exceção de PESSOA JORGE, "todos os outros autores se orientaram pela consideração como regra geral da irrelevância negativa da causa virtual" ${ }^{110}$. Portanto, com a exceção dos casos previstos em lei, a regra geral é a da irrelevância negativa da causa virtual.

Isso, no entanto, não quer dizer que a causa virtual não tenha o relevo de influenciar o quantum indenizatório, como acertadamente pontuou PEREIRA COELHO: "nada nos diz que a causa hipotética, que não tem relevo de excluir a causalidade do facto para o dano, não tenha o

\footnotetext{
${ }^{108}$ CRUZ, 2005, p. 253-254.

${ }^{109}$ PEREIRA COELHO, 1998, p. 214

${ }^{110}$ LEITÃO, 2002, p. 327-328.
} 
relevo de influir no montante do dano causado pelo facto" ${ }^{111}$. No mesmo sentido, CRUZ:

Com efeito, o fato de a causa virtual não afastar a relação de causalidade que liga a conduta do agente ao dano não significa, necessariamente, que o cálculo da indenização está livre de qualquer interferência sua. É que a causa virtual poderia influir na avaliação do dano a indenizar, sem excluir a causalidade do fato para o dano $^{112}$.

A razão para essa afirmação está na aplicação da teoria da diferença. Segundo essa teoria, positivada no art. 566, $\S 2^{\circ}$, do Código Civil português, a indenização em dinheiro será equivalente à diferença entre a situação patrimonial do lesado, na data mais recente que puder ser atendida pelo tribunal, e a que teria nessa data se não existissem danos ${ }^{113}$.

$\mathrm{Na}$ essência, portanto, realiza-se um cálculo aritmético, de forma que, se a situação patrimonial hipotética é igual à situação patrimonial efetiva, o resultado desta subtração é zero. Assim, pela aplicação da teoria da diferença, não haverá, em alguns casos, qualquer dano a indenizar. Dessa forma, como explica CRUZ, "se a causa virtual fosse capaz de produzir o dano antes do momento decisivo para o cálculo da indenização, a diferença entre a situação patrimonial efetiva do lesado e a sua hipotética seria igual a zero" $" 114$.

Para melhor demonstrar a forma de aplicação da teoria da diferença, recorra-se aos ensinamentos sempre esclarecedores de ANTUNES VARELA:

A danificou um objeto pertencente a $\mathrm{B}$, reduzindo-o a metade do seu valor normal. Este valor era de 300, na altura do dano, e de 500 na data em que o caso foi apreciado em juízo.

A várias diferenças se poderia atender, neste caso, para em tese geral se fixar o montante da indemnização devida:

\footnotetext{
${ }^{111}$ PEREIRA COELHO, 1998, p. 114.

112 CRUZ, 2005, p. 221.

113 ANTUNES VARELA, 2000, p. 907.

${ }^{114}$ CRUZ, op. cit., p. 223.
} 
A) À diferença entre a situação anterior ao facto (300) e a situação vigente à data da apreciação judicial da matéria (250). Dano igual a 50.

B) À diferença entre a situação anterior ao facto (300) e a situação imediatamente posterior a ele (150). Dano igual a 150.

C) À diferença entre a situação que existiria sem o facto, à data da apreciação judicial do caso (500), e a situação anterior ao facto (300). Dano igual a 200.

D) À diferença entre a situação hipotética actual (500) e a situação real da mesma data (250). Dano igual a 250.

A lei preferiu a última solução ${ }^{115}$.

Como se observa, é perfeitamente possível que uma causa virtual interfira na quantificação da indenização, afinal, basta que uma causa hipotética reduza o valor do dano após a sua ocorrência, mas antes da prolação da sentença, para que a causa virtual possua relevância negativa.

Imaginemos o seguinte exemplo: A danifica a casa de $\mathrm{B}$, reduzindo-a a metade do seu valor normal. Este valor, na altura do dano, era de R\$ 10 mil. Ocorre que, logo após o dano, o país em que está situada a casa entra em guerra, de modo que todos os imóveis daquela região sofrem uma desvalorização de 75\% (ou seja, a casa de B passou a valer $\mathrm{R} \$ 2.5$ mil). Nesse exemplo, aplicando-se a teoria da diferença, teríamos que A estaria obrigado a indenizar B no valor de R\$ 1.25 mil, ou seja, metade do valor atual do imóvel ${ }^{116}$.

$\mathrm{Na}$ mesma linha do exemplo acima, vejam-se as lições de NORONHA:

(...) é evidente que o autor da causa real não pode ser responsabilizado pelo dano que já tenha sido produzido pela causa virtual: é o que se chama de

\footnotetext{
${ }^{115}$ CRUZ, 2005, p. 221.

${ }^{116}$ Em igual sentido, consulte-se exemplo elucidativo elaborado por CRUZ: Caio destrói um bem de Tício que vale 100 . O bem, entretanto, não fosse a causa operante, sofreria uma desvalorização de 30 em razão de uma causa virtual. O problema da relevância negativa só se coloca em relação a esses 30, e não quanto aos 100. Isto é, ainda que se admita que a causa virtual tem relevância negativa, Caio jamais poderá valer-se dela para eximir-se da obrigação de indenizar (o máximo que ele poderia alegar é que só deve 70). Ibid., p. 219.
} 
responsabilidade pelo efeito parcial realmente produzido. Assim, se no momento em que a pessoa morreu, vítima de atropelamento, ela já estava muito doente e, segundo os médicos, com poucos meses de vida provável, a causa virtual (a doença) terá de ser considerada para redução da obrigação de indenizar do atropelante ao valor do dano patrimonial efetivamente causado (não cogitamos aqui do dano extrapatrimonial, que suscita algumas especificidades $)^{117}$.

Acreditamos ser essa a postura mais adequada. Afinal, ignorar por completo a desvalorização do bem danificado seria o mesmo que promover o enriquecimento ilícito do lesado. É isso que se propõe a fazer aqueles que defendem a relevância negativa da causa virtual no que tange à extensão da indenização.

Para CRUZ, salvo os casos expressamente previstos em lei, a causa virtual não possui relevância negativa, ainda que esta tenha se operado, antes, depois ou ao mesmo tempo da causa real. Segundo a autora, "a teoria da diferença, como bem salientou Galvão Telles, não deve sobrepor às exigências da justiça" ${ }^{118}$.

FROTA, em sentido contrário ao de CRUZ, entende ser admissível estender a relevância negativa da causa virtual para outras situações não expressas em lei, tendo em vista a concretização da equidade e da igualdade em cada caso concreto. $\mathrm{O}$ autor defende uma concepção ampla da relevância negativa da causa virtual:

\begin{abstract}
A teoria da diferença, neste sentido, trabalha com a ideia de desvalorização do valor de troca do bem material, mesmo que a causa virtual não o tenha atingido, como no caso relatado acima, da morte de pessoa previamente doente por atropelamento, ou no caso de um país que se encontra sob ameaça de guerra, o que gera a desvalorização de seus bens imóveis deste país. Dificuldade surge quando o bem atingido pelas causas se classifica como existencial, sendo inadequado se falar em "diminuição do valor do bem", a inviabilizar esta solução em tais casos (Sampaio da Cruz, 2005, p. 218). Pode-se aludir que a causa virtual também serve de parâmetro para os valores devidos a título de lucros cessantes e da indenização por renda (Ancona, 2008, p. 35).
\end{abstract}

Nessa linha, a teoria da diferença do patrimônio da vítima - "verificada no último momento possível (...) e se, devido à causa virtual, agora não existe diferença, não haveria a obrigação de indenizar" - somente pode ser utilizada para reduzir o

117 NORONHA, 2003, p. 588.

${ }^{118}$ CRUZ, 2005, p. 258. 
valor reparatório e não para excluir a causalidade. Dessa maneira, se o fato danoso originou o dano e, concomitantemente, impediu a produção de outro resultado danoso ou viabilizou vantagens, tais situações devem ser deduzidas do valor da reparação, por serem consequências adequadas do evento lesivo (Noronha, 2010, p. 694-695).

A relevância negativa da causa virtual, portanto, pode ser utilizada nas mencionadas hipóteses específicas de isenção total do dever de reparar pelo autor da causa real, nos casos expressos em lei e em outras situações em que se possa inferir tal pertinência, como aventado alhures. Serve também à redução do dever reparatório, sem, contudo, excluir a causalidade nos demais casos ${ }^{119}$.

Concordamos com a conclusão de FROTA, pois, ao contrário das hipóteses de relevância negativa da causa virtual para exclusão do dever de indenizar, as quais defendemos estarem restritas aos casos previstos em lei, a aplicação da teoria da diferença não encontra restrições legais. Não por outra razão, é essa também a conclusão de ANTUNES VARELA:

Das conclusões expostas resulta que a causa virtual não exonera o lesante da obrigação de indemnizar, salvo disposição legal em contrário. Isso não impede, porém, que a causa virtual do dano seja tomada na devida conta, quer no cálculo do lucro cessante, quer na adaptação da indemnização fixada sob a forma de renda às circunstâncias que vão sendo conhecidas pelos interessados ${ }^{120}$.

Pelo exposto, é possível concluir que (i) a causa virtual do dano não elimina a relação de causalidade existente entre a causa real e o dano; e (ii) a causa virtual do dano possui o condão de interferir na quantificação da indenização. Em outras palavras, a relevância negativa da causa virtual está restrita à extensão da indenização.

${ }^{119}$ FROTA, 2013, p. 158-160.

${ }^{120}$ ANTUNES VARELA, 2000, p. 936. 


\section{CONCLUSÃO}

A partir da análise doutrinária e jurisprudencial das teorias da causalidade, identificou-se a falta de certeza e precisão quanto à preponderância de uma ou outra teoria. A incerteza, fruto da dificuldade que o tema reclama, está evidenciada nas decisões judiciais dos Tribunais pátrios, os quais, além de aplicarem concomitantemente duas teorias - a da causalidade necessária e a da causalidade adequada -, muitas vezes se equivocam ao invocar fundamentos de uma corrente para embasar a aplicação de outra.

Pensamos, no entanto, não ser a incerteza das teorias da causalidade tão prejudicial à quantificação da indenização. O problema da causalidade "é insolúvel à base teórica"121, de modo que a aplicação conjunta de duas ou mais teorias, desde que pautada nos princípios de razoabilidade e proporcionalidade, é a que melhor atende à necessária ponderação entre, de um lado, o direito da vítima à indenização e, de outro, o direito do lesante de responder apenas pelo dano que efetivamente decorreu de sua conduta.

Viu-se, também, que é o nexo causal, e não a culpa, em regra, que deve nortear a quantificação da indenização, ou melhor, a distribuição da responsabilidade pela produção de determinado dano. Com efeito, o emprego da palavra "culpa” em algumas situações revela-se equivocado. Esse é o caso, como demonstrado, do termo "culpa concorrente da vítima", o qual, na realidade, trata da concorrência entre a causa do lesante e a do lesado.

No que tange ao concurso entre fato do lesante e condições preexistentes da vítima, expressamos a nossa crítica quanto à responsabilização do lesante pelo resultado mais grave. Esse entendimento, adotado pela jurisprudência, contraria não apenas a teoria da causalidade adequada, como também a teoria da causalidade necessária. Desse modo,

${ }^{121}$ DIREITO; FILHO, 2004, p. 85. 
tal responsabilização, à revelia das teorias acolhidas pelo ordenamento jurídico brasileiro, favorece o direito da vítima à indenização em detrimento do direito do lesante de ser condenado a indenizar apenas os danos decorrentes de sua conduta.

$\mathrm{Na}$ parte em que analisamos o concurso entre várias pessoas, evidenciamos aquilo que pretendíamos demonstrar com o presente trabalho, isto é, a necessidade de se quantificar a indenização de acordo com o grau de contribuição de cada agente. Assim, embora o valor global da indenização devida ao lesado seja a mesma - a menos que se esteja diante de um concurso de causas entre o lesante e a vítima, caso em que a indenização da vítima será reduzida na proporção de sua contribuição para a produção do dano -, o quantum atribuído a cada agente variará de acordo com o seu grau de participação.

Por fim, com relação ao concurso virtual de causas, demonstramos que a relevância negativa da causa virtual é assunto extremamente polêmico e controvertido. De todo modo, conquanto exista forte resistência à aceitação da relevância negativa da causa virtual para fins de exclusão do nexo causal, a doutrina é pacífica no sentido de aceitar a sua relevância na verificação da extensão do dano. Em outras palavras, admite-se a concorrência virtual de causas como fator relevante para a quantificação da indenização.

Com base nessas considerações, espera-se que o presente trabalho tenha contribuído para uma análise acurada acerca da importância da causalidade para a determinação do quantum indenizatório. Em meio às incertezas e complexidades próprias da importância do presente tema, a melhor orientação parece ser aquela que se sensibilize em equilibrar o direito da vítima à indenização e o direito do lesante de não ser condenado a indenizar os danos estranhos à sua conduta. 


\section{REFERÊNCIAS BIBLIOGRÁFICAS}

AGUIAR DIAS, José de. Da responsabilidade civil. v. 1, 9ª ed., Rio de Janeiro: Forense, 1994.

ALMEIDA COSTA, Mário Júlio de. Direito das Obrigações. $6^{\mathrm{a}}$ ed. Coimbra: Almedina, 1994.

Direito da Obrigações. 10ª ed. Coimbra: Almedina, 2006.

ALVIM, Agostinho. Da inexecução das obrigações e suas consequências. São Paulo: Saraiva, 1972.

ANTUNES VARELA, João de Matos. Das obrigações em geral. v. I. Coimbra: Almedina, 2000.

BRASIL. STJ, AgInt no AgRg no AREsp 227.905/RS, Rel. Min. Napoleão Nunes Maia Filho, $1^{\mathrm{a}}$ Turma, j. 21.08.18.

BRASIL. STJ, AgRg no AREsp 181235/SP, Rel. Min. Luis Felipe Salomão, $4^{\text {a }}$ Turma, j. 19.05.16.

BRASIL. STJ, EREsp 605.435, Rel. para acórdão Min. Raul Araújo, $2^{\mathrm{a}}$ Seção, j. 14.09.11.

BRASIL. STJ, EREsp 705859/SP, Rel. Min. Castro Filho, 2a Seção, j. 13.12.06.

BRASIL. STJ, REsp 1034302/RS, Rel. Min. Nancy Andrighi, $3^{\mathrm{a}}$ Turma, j. 12.04.11.

BRASIL. STJ, REsp 325.622/RJ, Rel. Des. convocado Carlos Fernando Mathias, $4^{\mathrm{a}}$ Turma, j. 28.10.08.

BRASIL. STJ, REsp 725.963/RJ, Rel. Min. NANCY ANDRIGHI, $3^{\mathrm{a}}$ Turma, j. 23.02.10.

CAVALIERI FILHO, Sérgio. Programa de Responsabilidade Civil. 11 ${ }^{\mathrm{a}} \mathrm{ed}$, São Paulo: Atlas, 2014.

CRUZ, Gisela Sampaio da. O Problema do Nexo Causal na Responsabilidade Civil. Rio de Janeiro: Renovar, 2005. 
DIREITO, Carlos Alberto Menezes; FILHO, Sérgio Cavalieri. Comentários ao novo Código Civil. TEIXEIRA, Sálvio de Figueiredo (Coord.). v. 13, t. II, Rio de Janeiro: Forense, 2004.

EWALD, François. Foucault, a Norma e o Direito. 2a ed. Lisboa: Vega, 2000 .

FERREIRA DA SILVA, Jorge Cesa. Inadimplemento das Obrigações. São Paulo: Revista dos Tribunais, 2006.

FIGUEIREDO, Luciano; FIGUEIREDO, Roberto. Direito Civil: Direito das Obrigações e Responsabilidade Civil. Salvador: JusPodivm, 2015.

FROTA, Pablo Malheiros da Cunha. A imputação sem nexo causal e a responsabilidade por danos. Curitiba, 2013. Tese (Doutorado). Universidade Federal do Paraná.

GONÇALVES, Carlos Roberto. Direito civil brasileiro. $5^{\text {a }}$ ed. São Paulo: Saraiva, 2010.

LARENZ, Karl. Derecho de Obligaciones. t. I. Madrid: Editorial Revista de Derecho Privado, 1958.

LEITÃO, Luís Manuel Teles de Menezes. Direitos das Obrigações. v. I. Coimbra: Almedina, 2002.

MARTINS-COSTA, Judith. Provocações canelenses acerca da concausalidade. In: MARTINS-COSTA, Judith. Comentários ao Código Civil. Do Inadimplemento das Obrigações. Rio de Janeiro, v. V, t. II., $2^{\mathrm{a}}$ ed, p. 502-516, Forense, 2009.

MELO DA SILVA, Wilson. Dano Moral. In: Enciclopédia Saraiva do Direito. São Paulo: Saraiva, v. 22, 1977.

NORONHA, Fernando. Direito das Obrigações. São Paulo: Saraiva, 2003.

O nexo de causalidade na responsabilidade civil. In: Revista dos Tribunais. v. 816, 2003.

PEREIRA COELHO, Francisco Manuel. O problema da causa virtual na responsabilidade civil. Coimbra: Livraria Almedina, 1998.

PEREIRA, Caio Mário da Silva. Responsabilidade civil. $5^{\mathrm{a}}$ ed. Rio de Janeiro: Forense, 1994. 
PESSOA JORGE, Fernando. Ensaio sobre os Pressupostos da Responsabilidade Civil. Coimbra: Almedina, 1999.

PONTES DE MIRANDA, Francisco Cavalcanti. Tratado de Direito Privado. t. XXII. Rio de Janeiro: Borsoi, 1958.

Tratado de direito privado. t. XXII. $3^{\mathrm{a}}$ ed. Rio de Janeiro: Editora Borsoi, 1971.

PORTUGAL. STJ, Processo $\mathrm{n}^{\mathrm{o}}$ 02B4369, $\mathrm{n}^{\mathrm{o}}$ do documento: SJ200302130043697, Rel. Min. Oliveira Barros, j. 13.02.2003.

PUTNEY, Vosburg V., 86 Wis. 278, 56 N.W. 480, 1893 Wisc. LEXIS 133 (Wis. 1893).

SANSEVERINO, Paulo. Princípio da Reparação Integral. São Paulo: Saraiva.

SCHREIBER, Anderson. Novos Paradigmas da Responsabilidade Civil: da erosão dos filtros da reparação à diluição dos danos. São Paulo: Atlas, 2007.

TEPEDINO, Gustavo. Notas sobre o nexo de causalidade. Revista Trimestral de Direito Civil. Rio de Janeiro, v. 6, Abr./Jun. 2001. 